Santa Clara University

Scholar Commons

Environmental Studies and Sciences

College of Arts \& Sciences

$10-2014$

\title{
Aridification of Central Asia and uplift of the Altai and Hangay mountains, Mongolia: stable isotope evidence
}

Jeremy K. Caves

Derek J. Sjostrom

Hari T.Mix

Santa Clara University,hmix@scu.edu

Matthew J. Winnick

C. Page Chamberlain

Follow this and additional works at: http://scholarcommons.scu.edu/ess

Part of the Environmental Studies Commons

\section{Recommended Citation}

Caves, J.K., Sjostrom, D., Mix, H.T., Winnick, M., Chamberlain, C.P. (2014). Stable isotope constraints on aridity in northern Central Asia and implications for the uplift history of the Altai and Hangay. American Journal of Science, vol. 314, no. 8, 1171-1201.

Reproduced by permission of the American Journal of Science.

DOI 10.2475/08.2014.01

This Article is brought to you for free and open access by the College of Arts \& Sciences at Scholar Commons. It has been accepted for inclusion in Environmental Studies and Sciences by an authorized administrator of Scholar Commons. For more information, please contact rscroggin@scu.edu. 


\title{
American Journal of Science
}

\author{
OCTOBER 2014
}

\section{ARIDIFICATION OF CENTRAL ASIA AND UPLIFT OF THE ALTAI AND HANGAY MOUNTAINS, MONGOLIA: STABLE ISOTOPE EVIDENCE}

\author{
JEREMY K. CAVES ${ }^{* \dagger}{ }^{\dagger}$, DEREK J. SJOSTROM**, HARI T. MIX*, \\ MATTHEW J. WINNICK*, and C. PAGE CHAMBERLAIN*
}

\begin{abstract}
Central Asia has become increasingly arid during the Cenozoic, though the mechanisms behind this aridification remain unresolved. Much attention has focused on the influence and uplift history of the Tibetan Plateau. However, the role of ranges linked to India-Asia convergence but well north of the Plateau-including the Altai, Sayan, and Hangay-in creating the arid climate of Central Asia is poorly understood. Today, these ranges create a prominent rain shadow, effectively separating the boreal forest to the north from the deserts of Central Asia. To explore the role of these mountains in modifying climate since the late Eocene, we measured carbon and oxygen stable isotopes in paleosol carbonates from three basins along a $650 \mathrm{~km}$ long transect at the northern edge of the Gobi Desert in Mongolia and in the lee of the Altai and Hangay mountains. We combine these data with modern air-parcel backtrajectory modeling to understand regional moisture transport pathways at each basin. In all basins, $\delta^{13} \mathrm{C}$ increases, with the largest increase in western Mongolia. The first $\delta^{13} \mathrm{C}$ increase occurs in central and southwestern Mongolia in the Oligocene. $\delta^{13} \mathrm{C}$ again increases from the upper Miocene to the Quaternary in western and southwestern Mongolia. We use a $1-D$ soil diffusion model to demonstrate that these $\delta^{13} \mathrm{C}$ increases are linked to declines in soil respiration driven by dramatic increases in aridity. Using modern-day empirical relations between mean annual precipitation and soil respiration, we estimate that precipitation has likely more than halved over the Neogene. Given the importance of the Hangay and Altai in steering moisture in Mongolia, we attribute these changes to differential surface uplift of the Hangay and Altai. Surface uplift in the Hangay began by the early Oligocene, blocking Siberian moisture and aridifying the northern Gobi. In contrast, surface uplift of the Altai began in the late Miocene, blocking moisture from reaching western Mongolia. Thus, the northern Gobi became increasingly arid east to west since the late Eocene, likely driven by orographic development in the Hangay during the Oligocene and the Altai in the late Miocene through Pliocene.
\end{abstract}

Key words: Stable isotopes, Mongolia, Altai Mountains, tectonic-climate interactions, terrestrial paleoclimate, Cenozoic

\section{INTRODUCTION}

Eastern Central Asia, stretching from eastern Kazakhstan to eastern Mongolia, is one of the largest arid regions on the planet. Bounded by the Tibetan Plateau and Himalayas in the south, the East Asian monsoon in the east, and the boreal forest to the north, the driving mechanisms that established this large arid region remain unclear. Over the Cenozoic, Central Asia has become increasingly arid, with significant aridifi-

* Department of Environmental Earth System Science, Stanford University, 473 Via Ortega, Rm. 140, Stanford, California 94305 USA

** Geology Program, Rocky Mountain College, Billings, Montana 59102, USA

† Corresponding Author: Department of Environmental Earth System Science, 473 Via Ortega, Rm. 140, Stanford, California 94305 USA; jcaves@stanford.edu 


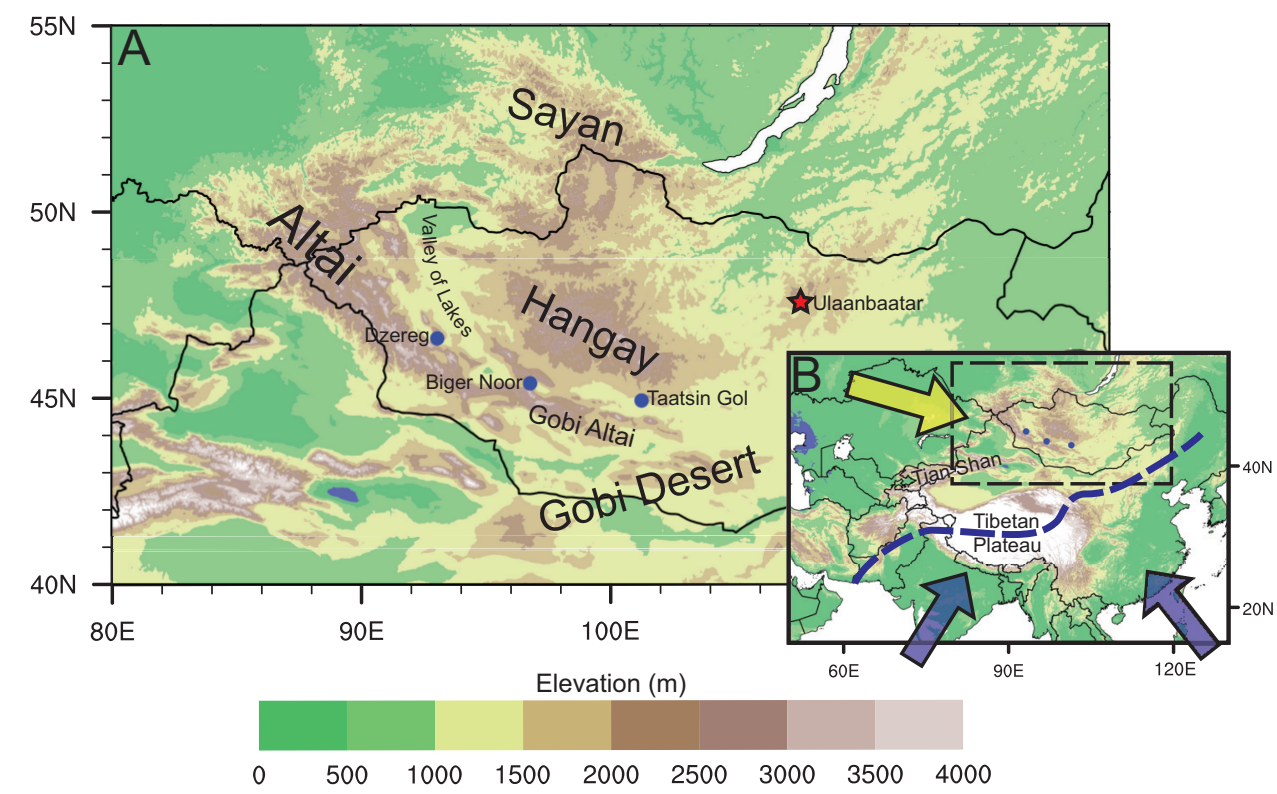

Fig. 1. Location map (A) with major physiographic features and studied basins labeled (blue circles). Inset (B) shows major pathways of moisture delivery to Central Asia. Dashed box shows area enclosed in (A). Yellow arrow shows approximate flow of westerly moisture, while blue arrows show flow directions of monsoonal moisture (South and East Asian monsoons). Blue, dashed line marks approximate inland extent of monsoonal moisture [adapted from Chen and others (2010)].

cation events at the Eocene-Oligocene (E-O) boundary (Dupont-Nivet and others, 2007; Kraatz and Geisler, 2010), near the Oligocene-Miocene boundary (Guo and others, 2002; Guo and others, 2008; J. Sun and others, 2010), and during the mid-late Miocene (Dettman and others, 2003; Hough and others, 2011; Zhuang and others, 2011; Miao and others, 2012). Simultaneously, the collision of India and Asia has uplifted the Tibetan Plateau and created a number of mountain ranges extending to the north (Molnar and others, 2010; Yin, 2010), while global climate has progressively cooled (Zachos and others, 2001).

Much of this aridification in Central Asia has been attributed to the progressive uplift of the Tibetan Plateau, which is thought to block northward flow of moist, subtropical air and produce subsiding air over Central Asia, suppressing large-scale convective systems (Sato and Kimura, 2005; Molnar and others, 2010). However, few studies have focused on understanding the role of orography north of the Plateau in establishing this aridity. An impressive array of mountain chains lie considerably north of the Plateau (including the Altai, Sayan, and Hangay; fig. 1) that are thought to be linked to India-Asia convergence (Tapponnier and Molnar, 1979; Yin, 2010), but the uplift histories of these northern ranges are poorly constrained. Apatite fission-track (AFT) dating indicates recent unroofing of the Altai and Sayan in the late Miocene and Pliocene (Vassallo and others, 2007; Buslov and others, 2008; De Grave and others, 2009; Delvaux and others, 2013; De Grave and others, 2014); yet, structural, sedimentological, and geomorphic evidence are suggestive of an older, broader-wavelength uplift in the Oligocene centered near the Hangay and Sayan (Cunningham, 2001; Howard and others, 2003; Jolivet and others, 2013; West and others, 2013).

These ranges exert a measurable impact on climate in Central Asia. They create a prominent rain shadow in the summer, with significantly more rainfall on their 
northern windward sides than on their southern leeward sides (Schneider and others, 2011). Chung and others (1976) and Chen and others (1991) found that the Altai-Sayan-Hangay are the single largest source of cyclogenesis in Asia, particularly in the spring, summer, and fall. Park and others (2010) demonstrated that it is the existence of these northern Central Asian ranges that both compress the winter-time westerlies to the south of the Himalayas and alter mid-winter storminess across the Pacific [see also Penny and others (2010)] and the entire Northern Hemisphere. Further, Roe (2009) argued that cyclones generated off the Altai in spring are responsible for entraining dust that is ultimately transported to the Loess Plateau. Therefore, better constraints on the timing and mechanisms of aridity in northern Central Asia could disentangle the relative roles of Tibetan Plateau uplift, northern Central Asia uplift, and global climate in shaping the modern climate of Central Asia.

In this paper, we present Eocene to Quaternary paleosol carbonate stable isotope data collected from three sedimentary basins (Taatsin Gol, Biger Noor, and Dzereg) along a $650 \mathrm{~km}$-long transect on the northern and western boundary of the Gobi Desert in Mongolia to better understand the climatic evolution of Central Asia (fig. 1). All are located within the Valley of Lakes Depression-a broad valley that separates the high peaks and plateaus of the Gobi Altai and Altai from the Hangay. These data constitute the northernmost stable isotope data set collected in Asia and, as a consequence, help constrain the timing and extent of aridification in the northern Gobi Desert during the Cenozoic. We combine this dataset with air parcel backtrajectory modeling to demonstrate the importance of the Altai and Hangay in steering moisture transport in Mongolia. Using a one-dimensional soil $\mathrm{CO}_{2}$ diffusion model, we quantify the precipitation decrease required to explain our stable isotope records. Finally, we show that the establishment of aridity in the northern and western portions of the Gobi Desert can be linked to surface uplift of these northern Central Asian mountains. The timing of these uplifts, which occurs during the Oligocene in the Hangay and during the late Miocene through Pliocene in the Altai, has implications both for the climatic evolution of Central Asia as well as for tectonic models of India-Asia convergence.

\section{MODERN MONGOLIA CLIMATE}

Modern climate in Mongolia is strongly continental, with January mean temperatures of $-19{ }^{\circ} \mathrm{C}$ and July mean temperatures of $20^{\circ} \mathrm{C}$ (Gerelchuluun and Ahn, 2013). Precipitation consists of steep rainfall gradients north to south (figs. 2 and A2 and Appendix 2), which are reflected by dramatic changes in vegetation throughout the country. Much of southern Mongolia is located within the Gobi Desert and is comprised of desert steppe and desert vegetation, while northern Mongolia, less than $500 \mathrm{~km}$ away, is forest steppe or taiga (Nandintsetseg and Shinoda, 2011). The south and west of Mongolia is particularly arid, with less than $150 \mathrm{~mm}$ rainfall annually (fig. A2 and Appendix 2). Most of the precipitation across the country is delivered in the summer, with 60 to 70 percent of total precipitation falling in June, July, and August (Endo and others, 2006; Nandintsetseg and Shinoda, 2011). During the winter, precipitation is negligible across much of the country due to a stationary high-pressure system-the Siberian High-centered over Mongolia and Siberia (Lydolph, 1977; Panagiotopoulos and others, 2005).

\section{HYSPLIT Modeling}

Broadly, the westerlies dominate moisture transport to Mongolia (Numaguti, 1999; Sato and others, 2007). However, given the complex topography of the Altai, Gobi Altai, and Hangay in western, southwestern, and central Mongolia, there are relatively few constraints on regional moisture transport pathways to specific sites in Mongolia. Therefore, we utilize the Hybrid Single-Particle Lagrangian Trajectory 


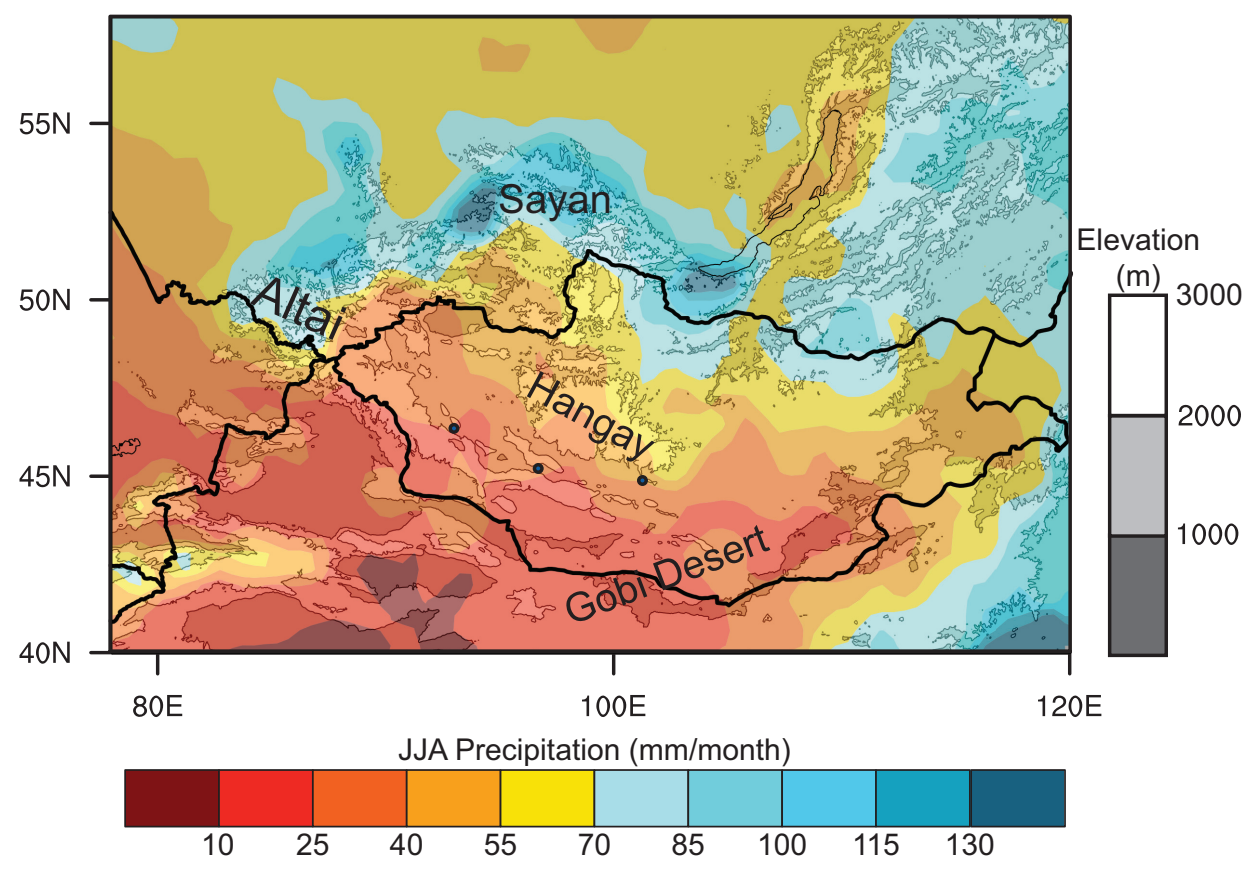

Fig. 2. Map of average June, July, and August (JJA) precipitation (1901-2010), compiled by the Global Precipitation Climatology Centre (Schneider and others, 2011), at $0.5^{\circ}$ by $0.5^{\circ}$ resolution overlaid on topography. The studied basins (blue circles) are located in basins with $40 \mathrm{~mm} / \mathrm{month}$ or less summer precipitation.

Model (HYSPLIT) combined with reanalysis model output from the Global Data Assimilation System (GDAS) (Draxler and Hess, 1998) to understand the modern pathway of air parcels at each of our geologic sampling locations and on the northern slopes of the Hangay. NOAA's Air Resources Laboratory regrids GDAS output to $1^{\circ} \times$ $1^{\circ}$ resolution, which is currently the best, HYSPLIT-compatible reanalysis output available for Central Asia.

For each location, we compute 75-hour back trajectories at 6-hour intervals for the years 2005-2013 for June, July, and August. At each location, we initialize back trajectories at 500,1000, 1500, 2000, and $3000 \mathrm{~m}$ above ground level to determine the sensitivity of the HYSPLIT model to initialization heights. Trajectories are filtered for only those trajectories that produce precipitation within 3 hours of the endpoint. Results show little dependence upon the precipitation filtering time (1-12 hrs before the endpoint). We present results (fig. 3) for trajectories initialized at $1000 \mathrm{~m}$ and also for a site on the northern flanks of the Hangay (fig. 3C) to contrast with sites on the southern flank, though we present no geologic data for this northern site.

HYSPLIT has been successfully used to study the origin and pathway of waters collected for isotopic analysis (Sjostrom and Welker, 2009; Sinclair and others, 2011; Bershaw and others, 2012) as well as trajectories for precipitation-producing air parcels around the Sierra Nevada (Lechler and Galewsky, 2013). There are, however, significant limitations when evaluating HYSPLIT results. First, we use GDAS reanalysis data, which, while reflecting a combination of observations and numerical weather models, is particularly imprecise in complex terrain (Kalnay and others, 1996; Gottschalck and others, 2005). Second, HYSPLIT does not track moisture; rather, it tracks air parcels 

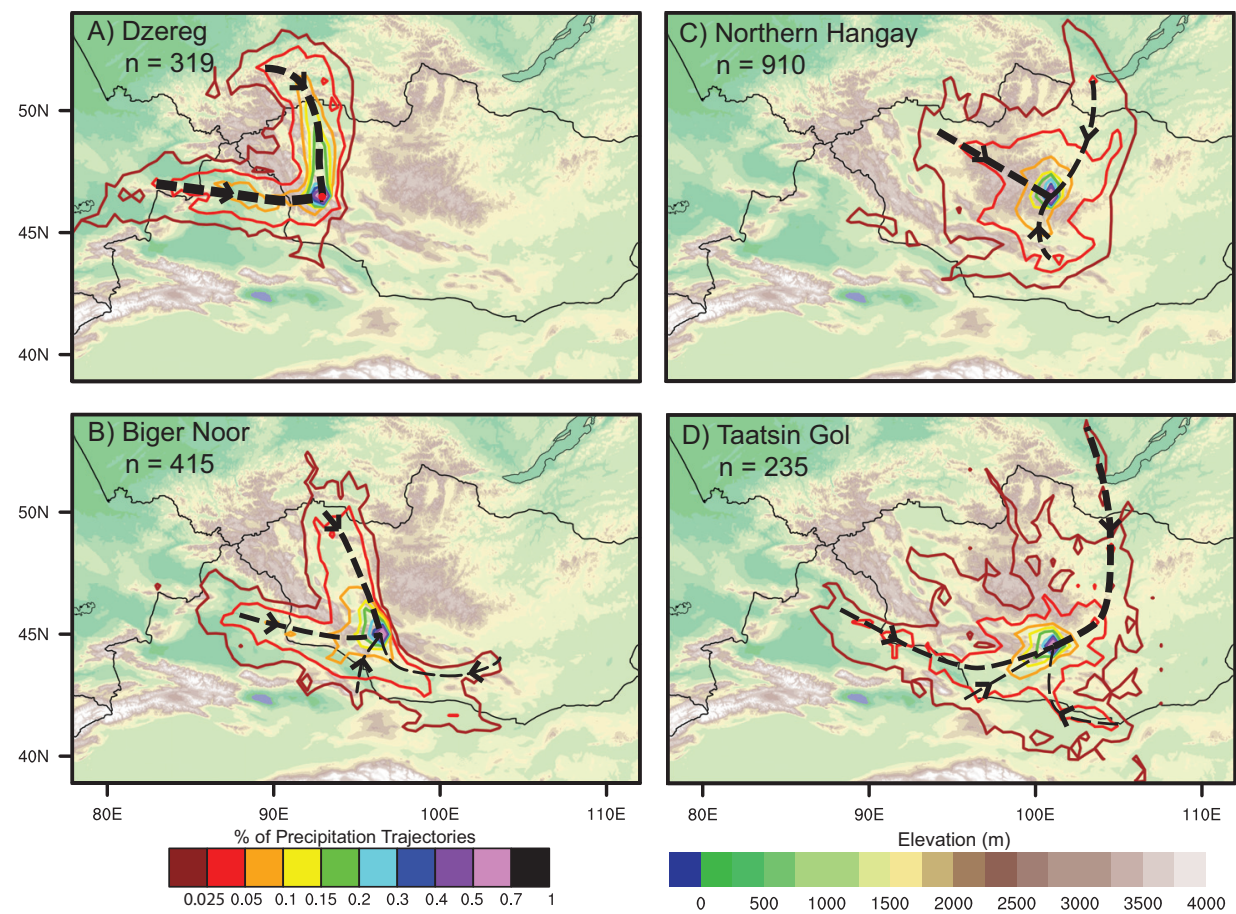

Fig. 3. Contour plots of precipitation-producing trajectories initialized at $1000 \mathrm{~m}$ generated by HYSPLIT and overlain on topography. Trajectories are binned by $0.5^{\circ}$ by $0.5^{\circ}$ to produce contours. Dashed lines are approximate mean trajectory routes, with arrow showing direction of travel. Thickness of the dashed line approximately corresponds to percentage of precipitation-producing trajectories represented by the mean trajectory. (A) Dzereg; (B) Biger Noor; (C) Northern Hangay; and (D) Taatsin Gol. Blue circles mark HYSPLIT initialization locations, and, at Dzereg, Biger Noor, and Taatsin Gol, roughly correspond to geologic sampling locations. A representative site from the northern flanks of the Hangay (C) is included to contrast with the trajectories patterns at Biger Noor (B) and Taatsin Gol (D), though we present no geologic data from this specific site. Note the higher number of precipitation-producing trajectories at the northern Hangay location.

without accounting for addition of moisture by evaporation or diffusion or removal of moisture through precipitation. Third, the $1^{\circ} \times 1^{\circ}$ resolution smoothes much of the complex topography in western and southwestern Mongolia. We overcome these limitations by filtering our trajectories for those estimated to have produced precipitation and by calculating 3,240 trajectories for each site.

\section{HYSPLIT Results}

Taatsin Gol receives the fewest precipitation-bearing trajectories, while the north slopes of the Hangay receive the most (fig. 3). The trajectory patterns at Dzereg (fig. 3A) display two primary paths: One from the north/northwest traveling along the Valley of Lakes and the other from the west over the southern Altai. Biger Noor (fig. 3B) displays a similar pattern, with the majority of trajectories following these two paths, but with a third path traveling from the southeast. The Valley of Lakes trajectory route is particularly evident at low initialization altitudes $(500 \mathrm{~m})$ and likely corresponds to convective systems that form within the Valley of Lakes. Interestingly, few trajectories come directly over the main mass of the Altai; rather, most trajectories that reach Biger Noor or Dzereg split around the Altai. As a roughly circular mountain range that projects into the path of the westerlies, these results suggest that the Altai 
currently split much of the flow around them [see Galewsky (2009)], and that the Valley of Lakes acts as a conduit that funnels moisture to much of western and southwestern Mongolia.

In the northern Hangay (fig. 3C), precipitation-bearing trajectories come primarily from the northeast (a result increasingly evident at low initialization altitudes), the west over the Hangay, or from the south. Nearly all of the non-precipitation producing trajectories come from the west (fig. A3 and Appendix 3), indicating that moisture flowing south from Siberia delivers significant moisture. At Taatsin Gol (fig. 3D), however, most trajectories come from the Valley of Lakes or southwest or over the low eastern Hangay, with few traveling over the highest part of the Hangay. Similarly, at Biger Noor, few trajectories travel over the high Hangay. These results suggest that the Hangay is responsible for a rain shadow-producing a steep precipitation gradient from the north slopes of the Hangay (wet) to the south and southwest side (dry). Biger Noor, in particular, appears to be influenced by both the Altai and the Hangay.

\section{GEOLOGIC SETTING AND METHODS}

To understand moisture changes in the past, we collected 117 samples, including paleosol carbonate nodules and caliches and interstitial calcites in fluvial siltstones and sandstones, from three basins across a $650 \mathrm{~km}$ swath in the Valley of Lakes. We classify all of the paleosols as aridisols following Retallack (1994). Late Eocene deposition in the Valley of Lakes is recorded locally, but Oligocene to Quaternary deposition is widespread. Below, we describe the studied sections (fig. 4) and address evidence for pedogenesis and diagenetic considerations in Appendix 1.

\section{Taatsin Gol}

Taatsin Gol (45.42N, 101.25E) is composed of late Eocene to mid-Miocene sediments (fig. 4C). These sections are described in detail by Höck and others (1999) and Daxner-Höck and Badamgarav (2007), who provide a geochronologic framework for these sections, as well as Kraatz and Geisler (2010), who provide magnetostratigraphic constraints across the E-O boundary. The chronology is tied to three interbedded basalts (dated at $31.5 \mathrm{Ma}, 28 \mathrm{Ma}$, and $13 \mathrm{Ma}$ ). The section is composed of three formations: (1) The Tsagaan Ovoo Fm., at the base of the section, consists of poorly sorted gravels and small amounts of carbonate-rich paleosols and is late Eocene in age; (2) The Hsanda Gol Fm., which lies conformably above the Tsagaan Ovoo, consists of fine-grained red beds with abundant carbonate-rich paleosols and contains the lowest interbedded basalt ( $31.5 \mathrm{Ma}$ ), though biostratigraphy suggests it extends up to $\sim 25 \mathrm{Ma}$ (Höck and others, 1999); (3) The Loh Fm., which lies unconformably above the Hsanda Gol Fm., contains both the middle and top interbedded basalts (28 Ma and 13 $\mathrm{Ma}$ ) and is composed of poorly sorted gravels with small amounts of calcite. We construct a composite section, with the lowest section from the Tsagaan Ovoo Fm. and Hsanda Gol Fm. below the 31.5 Ma basalt (fig. A4A), a middle section from the Hsanda Gol Fm. but above the $28 \mathrm{Ma}$ basalt, and the highest section from the Loh Fm. beneath the $13 \mathrm{Ma}$ basalt. At present, this locality is dissected by the Taatsin Gol (river), which drains the Hangay Mountains to the north into the inward-draining Valley of Lakes. Paleoflow indicators suggest north to south flow throughout the entire depositional sequence (Höck and others, 1999).

\section{Biger Noor}

Biger Noor $(45.9 \mathrm{~N}, 96.78 \mathrm{E})$ is composed of Oligocene to Quaternary sediments deposited on the western end of the current internally drained Biger basin. This basin is today separated from the Hangay to the northeast by a $2900 \mathrm{~m}$ high, NW-SE trending ridge. The locality is described in Gradzinski and others (1969), who provide a broad chronology for the section based upon biostratigraphic constraints. The lowest beds 


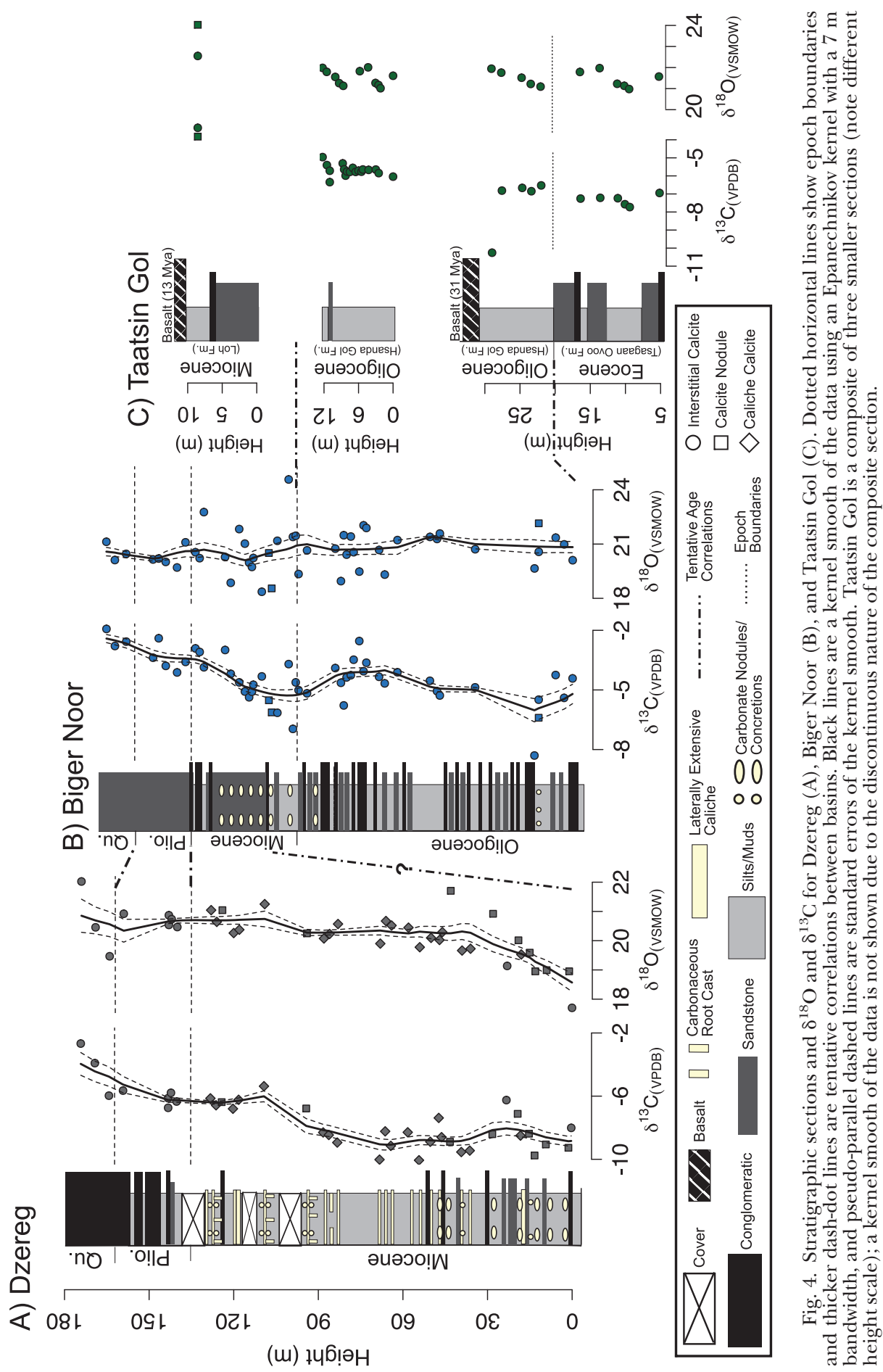


consist of red silts, sands, and conglomerates, poorly to medium cemented, of Oligocene age (figs. 4B and A4B). These beds dip to the southwest at $40^{\circ}$. Lying above these red beds is a series of yellowish, poorly sorted channels classified as Miocene (fig. A4D), which grade into coarser, braided channel deposits of Pliocene age. Quaternary alluvium caps the entire sequence. Carbonate-rich (as both interstitial calcite and infrequent nodules) fluvial channels are distributed throughout the section, most abundantly in the Oligocene and Miocene.

\section{Dzereg}

Dzereg $(47.14 \mathrm{~N}, 93.06 \mathrm{E})$ is an internally drained basin bounded by the Mongolian Altai on the west and a $3400 \mathrm{~m}$ high, NW-SE trending ridge in the Valley of Lakes on the east. Thick Mesozoic and Cenozoic sedimentary sequences are described by Gradzinski and others (1969) (termed the Altan Teli locality) and Howard and others (2003). Gradzinski and others (1969) provide broad age constraints based upon biostratigraphy. Though the Cenozoic sequences include Oligocene, the lowest Miocene and Oligocene sediments are poorly exposed; we therefore collected paleosol carbonates in Miocene to Quaternary exposures (fig. 4A). The Miocene consists of an upward fining, approximately $130 \mathrm{~m}$ thick section of interbedded silts and sand channels (fig. A4C). These channels are calcite rich and contain numerous carbonate nodules and concretions. Toward the upper Miocene, laterally extensive caliches become more abundant. The Pliocene sediments consist of well-cemented conglomeratic red beds that generally fine upward and contain abundant interstitial calcite. Quaternary fanglomerates cap the entire sequence.

\section{Stable Isotope Methods}

Samples were powdered using either a mortar and pestle or a Dremel. Stable C and $\mathrm{O}$ isotope values of carbonates were obtained at the Stable Isotope Biogeochemistry Laboratory, Stanford University, using a Thermo Finnigan Gasbench interfaced with a Thermo Finnigan Delta Plus XL mass spectrometer via a Thermo Finnigan ConFlo III unit. Depending on the samples' carbonate content, between 200 and 4,400 $\mu \mathrm{g}$ of sample powder was weighed into sealed vials that were flushed with $\mathrm{He}$ gas and reacted with $c a .0 .25 \mathrm{ml}$ of phosphoric acid $\left(\mathrm{H}_{3} \mathrm{PO}_{4}\right)$ for 1 hour at $72{ }^{\circ} \mathrm{C}$. External precision $(1 \sigma)$ of oxygen and carbon isotope data is generally $<0.1$ permil, based upon repeated measurements of two internal lab standards (calibrated against NBS 18, NBS 19 , and LSVEC). The $\delta^{13} \mathrm{C}$ values are reported relative to VPDB, $\delta^{18} \mathrm{O}$ values are reported relative to VSMOW.

\section{Age Assignments}

Samples were assigned ages based upon the chronologic constraints in Kraatz and Geisler (2010), Daxner-Höck and Badamgarav (2007), and Gradzinski and others (1969). The Taatsin Gol section is constrained by ${ }^{40} \mathrm{Ar} /{ }^{39} \mathrm{Ar}$ basalt geochronology, paleomagnetism, and biostratigraphy, while biostratigraphy provides the only age constraints for Biger Noor and Dzereg. Between age constraints, we have assumed constant sedimentation rate. Our section at Dzereg does not begin at the very base of the Miocene due to confusion regarding the exact contact between the Miocene, Oligocene, and lower Cretaceous at Dzereg (Gradzinski and others, 1969; Howard and others, 2003); thus, we have assigned the base of the Dzereg section as mid-early Miocene. Given these broad age constraints, we also present results binned by the broadest age constraint at each section, assuming (for Dzereg and Biger Noor) that the epoch-level classifications are correct.

\section{RESULTS}

Across all sections, the $\delta^{13} \mathrm{C}$ of paleosol carbonates varies from -10.3 permil to -1.9 permil, and $\delta^{18} \mathrm{O}$ ranges from 17.7 permil to 24.6 permil. Figure 4 shows $\delta^{13} \mathrm{C}$ and 

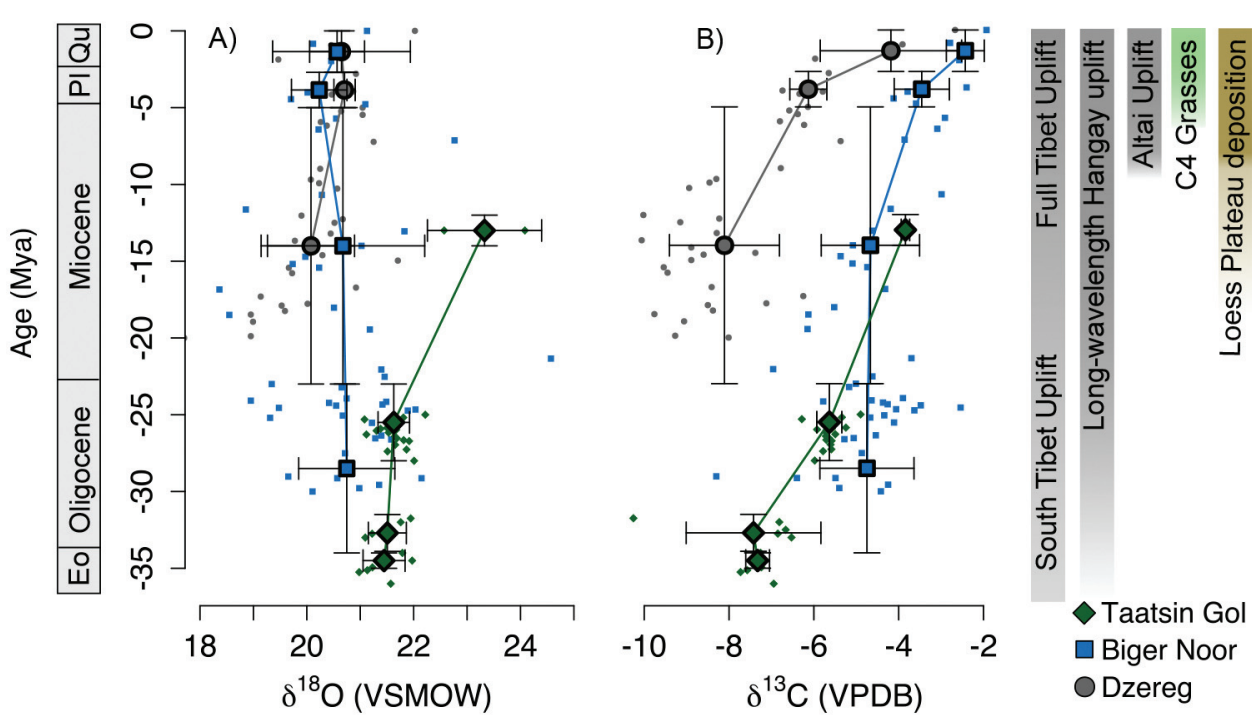

Fig. 5. Plot of $\delta^{18} \mathrm{O}$ and $\delta^{13} \mathrm{C}$ at all sections against estimated age. Plots (A) and (B) show all data points and large filled points are means of all points binned by broadest age constraint (epoch-level at Dzereg and Biger Noor). Age error bars (y-direction) show range of age, while $\delta$ error bars (x-direction) show 1 standard deviation. Bars to the right show estimated ages of tectonic and ecological changes. Shading indicates uncertainty regarding the timing of these events, with less shading indicating greater uncertainty.

$\delta^{18} \mathrm{O}$ plotted against stratigraphic position. Figure 5 shows this data plotted against our age assignments as well as binned by the broadest age constraint at each section with estimated ages of tectonic and ecological changes in Central Asia. Isotope ratio data are reported in table A7 (Appendix 7).

$\delta^{13} \mathrm{C}$ values increase in all sections. At Taatsin Gol, $\delta^{13} \mathrm{C}$ increases by 3.5 permil, with a continuous increase from the late Eocene to the mid-Miocene. $\delta^{13} \mathrm{C}$ values from the late Eocene to early Oligocene at Taatsin Gol are statistically lower than samples from the late Oligocene ( $\mathrm{p}<0.05$ using two-sided Student's t-test), which are, in turn, statistically lower than samples from the middle Miocene $(p<0.05$ using two-sided Student's t-test). At Biger Noor, there is considerably more variability, but overall, $\delta^{13} \mathrm{C}$ increases. $\delta^{13} \mathrm{C}$ values increase during the Oligocene by 1.2 permil, then increase again during the upper Miocene, Pliocene, and Quaternary by 2.8 permil. At Dzereg, $\delta^{13} \mathrm{C}$ values display the greatest increase upsection, increasing 5.5 permil from the upper Miocene to the Quaternary. In the lower Miocene, $\delta^{13} \mathrm{C}$ values at Dzereg are $\sim 4$ permil lower than samples from both Biger Noor and Taatsin Gol. By the Quaternary, however, Dzereg $\delta^{13} \mathrm{C}$ is -4.2 permil $\pm 1.7(1 \sigma)$ and Biger Noor $\delta^{13} \mathrm{C}$ is -2.4 permil \pm $0.4(1 \sigma)$, which is statistically identical ( $\mathrm{p}>0.05$ using two-sided Student's t-test).

The $\delta^{18} \mathrm{O}$ data show more subtle trends than the $\delta^{13} \mathrm{C}$ data. At Taatsin Gol, $\delta^{18} \mathrm{O}$ values in the Eocene-Oligocene part of the section are 21.6 permil $\pm 0.3(1 \sigma)$ and remain constant throughout this part of the section. The two mid-Miocene samples have higher $\delta^{18} \mathrm{O}$ values of 23.3 permil $\pm 1.1(1 \sigma)$, though this is not statistically significant $(\mathrm{p}>0.05$ using one sample Student's t-test). At Biger Noor, there is considerable variance in $\delta^{18} \mathrm{O}$ values, but they remain approximately constant at 20.5 permil $\pm 1.1(1 \sigma)$ throughout the section. Dzereg $\delta^{18} \mathrm{O}$ values increase 2 permil over the length of the section, much of it occurring in the Miocene at the bottom of the section, with relatively constant $\delta^{18} \mathrm{O}$ values of 20.6 permil $\pm 0.6(1 \sigma)$ in the upper part 
of the section. The means of Miocene to Quaternary $\delta^{18} \mathrm{O}$ values from Biger Noor and Dzereg are statistically indistinguishable ( $\mathrm{p}>0.05$ using two-sided Student's t-test).

At Dzereg, increases in $\delta^{18} \mathrm{O}$ and $\delta^{13} \mathrm{C}$ are diachronous. The $\delta^{13} \mathrm{C}$ values increase during the upper Miocene and Pliocene while $\delta^{18} \mathrm{O}$ values remain constant. Similarly, throughout the sections at both Taatsin Gol and Biger Noor, $\delta^{18} \mathrm{O}$ remains constant while $\delta^{13} \mathrm{C}$ increases.

Though we collected different types of pedogenic calcite (nodule, caliche, and interstitial), there is no statistical difference in $\delta^{18} \mathrm{O}$ among these types of calcite $(\mathrm{p}<$ 0.05 using two-sided Student's t-test) at Dzereg and Biger Noor. At Taatsin Gol, all but one of our samples is interstitial calcite. There are, however, statistical differences in the $\delta^{13} \mathrm{C}$ values among these types of calcite, which is a result of changing pedogenic calcite type within sections that correlate with changing $\delta^{13} \mathrm{C}$.

\section{DISCUSSION}

A variety of factors influence the $\delta^{13} \mathrm{C}$ and $\delta^{18} \mathrm{O}$ of paleosol carbonate. Below, we review the influences on $\delta^{13} \mathrm{C}$ and discuss the most probable reasons for the observed increase in $\delta^{13} \mathrm{C}$ at all sites. We then explore how climatic and topographic influences have driven the combined evolution of $\delta^{13} \mathrm{C}$ and $\delta^{18} \mathrm{O}$ at these sites.

\section{$\delta^{13}$ C Record}

The most robust trend in our stable isotope record is the increase in $\delta^{13} \mathrm{C}$ observed at all three sites. The $\delta^{13} \mathrm{C}$ of paleosol carbonate reflects mixing between atmospheric $\mathrm{CO}_{2}$-with a nominal $\delta^{13} \mathrm{C}$ value of -6.5 permil (Cerling, 1984; Tipple and others, 2010) - and soil respired $\mathrm{CO}_{2}$, which is depleted relative to the atmosphere. As a consequence, there are four mechanisms to increase $\delta^{13} \mathrm{C}$ in paleosol carbonates: (1) Changes in the photosynthetic pathway of the overlying plants from $\mathrm{C}_{3}$ to $\mathrm{C}_{4}$ plants, which have distinctly different isotopic ratios (means of $-27 \%$ and $-12.5 \%$, respectively) (Cerling and others, 1997); (2) Increases in aridity, which increase water use efficiency (WUE) and increase $\delta^{13} \mathrm{C}$ in $\mathrm{C}_{3}$ and $\mathrm{C}_{4}$ plant matter (Park and Epstein, 1960; Farquhar and others, 1982; Farquhar and others, 1989); (3) An increase in the ratio of atmospheric $\mathrm{CO}_{2}$ to soil respired $\mathrm{CO}_{2}$ in soils, driven either by increases in atmospheric $\mathrm{pCO}_{2}$ or decreases in soil respiration rates (Cerling, 1991; Cerling, 1999; Takeuchi and others, 2010; Myers and others, 2012); and (4) a shallowing of soil carbonate formation, often driven by an increase in aridity (Retallack, 2005). Below, we discuss the importance of these mechanisms in our $\delta^{13} \mathrm{C}$ record.

\section{Changes in $C_{3} / C_{4}$ Vegetation}

We exclude changes in $\mathrm{C}_{3} / \mathrm{C}_{4}$ vegetation as the dominant control on our $\delta^{13} \mathrm{C}$ records due to the northward latitude of these basins, the timing of the $\delta^{13} \mathrm{C}$ increase at these sites, and the small proportion of $\mathrm{C}_{4}$ flora currently found in Mongolia. First, most increases in paleosol carbonate and fossil-tooth enamel $\delta^{13} \mathrm{C}$ observed in the Neogene are attributed to changes in the relative abundance of $\mathrm{C}_{3}$ versus $\mathrm{C}_{4}$ vegetation (Cerling and others, 1997; Passey and others, 2009, and references therein). For many locations, this interpretation may be accurate, as most paleosol carbonate sections are no more than $40^{\circ}$ poleward. However, beyond $40^{\circ}$, climate is generally predicted to be unfavorable for $\mathrm{C}_{4}$ vegetation (Collatz and others, 1998; Still and others, 2003). Indeed, a global compilation of fossil-tooth enamel by Passey and others (2009) found Neogene tooth enamel collected above $45^{\circ}$ showed no $\mathrm{C}_{4}$ influence. Taatsin Gol, Biger Noor, and Dzereg all lie north of $45^{\circ}$, indicating that the trend seen in $\delta^{13} \mathrm{C}$ is likely not due to changes in the abundance of $\mathrm{C}_{3}$ versus $\mathrm{C}_{4}$ vegetation.

Second, the $\delta^{13} \mathrm{C}$ increase at Taatsin Gol and Biger Noor during the Oligocene pre-dates the rise of $\mathrm{C}_{4}$ plants globally. Cerling and others (1997) dated the global rise of $\mathrm{C}_{4}$ plants to between 8 and $6 \mathrm{Ma}$ based upon fossil-tooth enamel. Zhang and others 
(2009) found that $\mathrm{C}_{4}$ plants did not expand into Inner Mongolia grasslands until the late Miocene. However, given the broad age constraints at Dzereg and Biger Noor, we cannot rule out that the Miocene and Pliocene $\delta^{13} \mathrm{C}$ increase at these sections coincides with the global rise of $\mathrm{C}_{4}$ vegetation.

Third, $\mathrm{C}_{4}$ plants today are not abundant in Mongolia, particularly at the northern edge of the Gobi Desert; however, some $\mathrm{C}_{4}$ plants that are particularly well-adapted to cold environments do exist in the Gobi (Pyankov and others, 2000; Toderich and others, 2007). Although these authors do not quantify the abundance of $\mathrm{C}_{4}$ plants relative to $\mathrm{C}_{3}$ plants, they do note that $\mathrm{C}_{4}$ species make up no more than approximately 15 percent of the total species in the Gobi. Other authors note that the Mongolian steppe (Wittmer and others, 2008) and central Inner Mongolia (Zhang and others, 2009) are dominated by $C_{3}$ grasses. These lines of evidence suggest that, at most, $\mathrm{C}_{4}$ vegetation likely comprises no more than 15 percent of the total biomass in southern Mongolia. Assuming $\delta^{13} \mathrm{C}_{\text {of }} \mathrm{C}_{3}$ plants as -27 permil, of $\mathrm{C}_{4}$ plants as -12.5 permil, and a maximum abundance of $\mathrm{C}_{4}$ plants of 15 permil, $\mathrm{C}_{4}$ plants could have increased average plant matter $\delta^{13} \mathrm{C}$ - and by extension, paleosol carbonate $\delta^{13} \mathrm{C}$-a maximum of 2 permil over the late Neogene. We note that this estimate is almost certainly a maximum because, while $\mathrm{C}_{4}$ plants may comprise up to 20 percent of the species richness, they likely comprise a substantially lower percentage of the total biomass (Wittmer and others, 2008; Zhang and others, 2009). Thus, at Dzereg, $\mathrm{C}_{4}$ plants can only explain approximately half of the 5.5 permil change in $\delta^{13} \mathrm{C}$ during the late Neogene. While this could explain the entire increase in $\delta^{13} \mathrm{C}$ at Biger Noor, the preponderance of evidence-including the northern location of Biger Noor, the low abundance of $\mathrm{C}_{4}$ plants in modern Mongolian flora, and a $\delta^{13} \mathrm{C}$ increase in both the Oligocene and a tentatively dated mid-Miocene increase in $\delta^{13} \mathrm{C}$-suggests that the global expansion of $\mathrm{C}_{4}$ plants during the late Neogene does not explain the bulk of the $\delta^{13} \mathrm{C}$ increase observed in our sections. As a consequence, we exclude the expansion of $\mathrm{C}_{4}$ plants as the dominant driver of increasing $\delta^{13} \mathrm{C}$ observed in these paleosol carbonates.

\section{Changes in Aridity}

Increases in aridity can act to increase the $\delta^{13} \mathrm{C}$ of soil carbonate in three ways: (1) An increase in plant matter $\delta^{13} \mathrm{C}$ due to water stress and photosynthesis becoming more diffusion limited (Park and Epstein, 1960; Farquhar and others, 1982; Kohn, 2010); (2) A decrease in plant productivity (Knapp and Smith, 2001; Huxman and others, 2004), which decreases soil respiration (SR), and increases the ratio of atmospheric $\mathrm{CO}_{2}$ to soil respired $\mathrm{CO}_{2}$ (Cerling, 1984; Takeuchi and others, 2010); and (3) a shallowing of soil carbonate formation due to reduced infiltration. These processes act in concert to increase soil carbonate $\delta^{13} \mathrm{C}$. The first process, however, likely accounts for only a small portion of the increase in $\delta^{13} \mathrm{C}$ observed in each section. Wittmer and others (2008) found only an $\sim 1.5$ permil change in the $\delta^{13} \mathrm{C}$ of modern $\mathrm{C}_{3}$ plant matter across a wide precipitation gradient $(100-300 \mathrm{~mm}$ annually) in the Mongolian steppe, while Kohn (2010) found an only 2 permil change from semi-arid to arid ecosystems ( $<400 \mathrm{~mm}$ annually). In contrast, decreases in productivity at already semi-arid locales can potentially drive large $\left(>5 \%\right.$ ) changes in $\delta^{13} \mathrm{C}$. In productive systems, changes in SR have little effect on soil $\mathrm{CO}_{2} \delta^{13} \mathrm{C}$. However, in desert or semi-desert environments similar to modern-day Mongolia (with SR ranging from 50 to $225 \mathrm{gC} / \mathrm{m}^{2} / \mathrm{yr}$ ), small changes in SR can measurably change the ratio of atmospheric to soil respired $\mathrm{CO}_{2}$, altering soil $\mathrm{CO}_{2} \delta^{13} \mathrm{C}$ (Cerling, 1984; Cerling, 1991; Raich and Schlesinger, 1992; Cerling and Quade, 1993).

Though it is difficult to parse the relative contribution of changing plant matter $\delta^{13} \mathrm{C}$ and decreases in productivity to increases in soil carbonate $\delta^{13} \mathrm{C}$, we can begin to place bounds on the decrease in precipitation-and consequent increase in aridity- 
required to reproduce the shifts in $\delta^{13} \mathrm{C}$ observed in our sections. First, we use the one-dimensional soil $\mathrm{CO}_{2}$ diffusion model (eq 1) of Cerling (1984) solved at steadystate and assume constant soil $\mathrm{CO}_{2}$ production with depth:

$$
C_{s}=\frac{\theta}{D_{s}}\left(L z-\frac{z^{2}}{2}\right)+C_{a t m}
$$

where $\mathrm{C}_{\mathrm{s}}$ is the soil $\mathrm{CO}_{2}$ concentration $\left(\mathrm{mols} / \mathrm{cm}^{3}\right)$, $\mathrm{L}$ is the production depth of $\mathrm{CO}_{2}$ $(\mathrm{cm}), \theta$ is the constant soil $\mathrm{CO}_{2}$ production rate $\left(\mathrm{mols} / \mathrm{cm}^{3} / \mathrm{s}\right)$, where $\mathrm{SR}=\theta \times \mathrm{L}, \mathrm{C}_{\mathrm{atm}}$ is the atmospheric concentration of $\mathrm{CO}_{2}\left(\mathrm{mols} / \mathrm{cm}^{3}\right), \mathrm{D}_{\mathrm{s}}$ is the diffusion coefficient for $\mathrm{CO}_{2}\left(\mathrm{~cm}^{2} / \mathrm{s}\right)$, and $\mathrm{z}$ is depth in the soil $(\mathrm{cm})$. Second, we solve for SR and, following Davidson (1995) and Cerling (1999), insert the appropriate isotopic relations for ${ }^{13} \mathrm{CO}_{2}$ :

$$
S R=\frac{1}{\varepsilon}\left[\frac{D_{s} C_{a t m}\left(\delta_{a t m}-\delta_{s}\right)}{\left(L z-\frac{z^{2}}{2}\right)\left(\delta_{s}-1.0044 \delta_{\theta}-4.4\right)}\right] L
$$

where $\delta_{\theta}$ is the $\delta^{13} \mathrm{C}$ of soil-respired $\mathrm{CO}_{2}$ and assumed to be the value typical of $\mathrm{C}_{3}$ plants $\left(-27 \%\right.$ ) (Kohn, 2010); $\delta_{\text {atm }}$ is the $\delta^{13} \mathrm{C}$ of atmospheric $\mathrm{CO}_{2}\left(-6.5 \%\right.$ ) ; and $\delta_{\mathrm{s}}$ is the $\delta^{13} \mathrm{C}$ of soil $\mathrm{CO}_{2}$ and is calculated from the measured $\delta^{13} \mathrm{C}$ of carbonate assuming equilibrium fractionation between soil $\mathrm{CO}_{2}$ and calcite at $15^{\circ} \mathrm{C}$ using the fractionation factors compiled in Cerling (1999). Because soil respired $\mathrm{CO}_{2}$ is produced entirely within the soil pore space, we correct for the porosity $(\varepsilon)$ with the first term in equation 2, following Cerling (1991). We constrain $\mathrm{C}_{\mathrm{atm}}$ using published Cenozoic $\mathrm{pCO}_{2}$ estimates (Beerling and Royer, 2011; Bartoli and others, 2011; Foster and others, 2012; Zhang and others, 2013), which we smooth using a 1 Ma bandwidth Epanechnikov kernel (fig. A5 and Appendix 5). Remaining equation parameters are listed in table 1. All calculations assume sampled soil carbonates formed at a depth (z) of $50 \mathrm{~cm}$. Though decreases in the depth of formation of soil carbonate can increase $\delta^{13} \mathrm{C}\left(\delta_{\mathrm{s}}\right)$, we explore the sensitivity of equation 2 to changing $\mathrm{z}$ in Appendix 6 (see also fig. A6).

Third, using equation 2, we can approximate the required decrease in SR needed to explain the observed $\delta^{13} \mathrm{C}$ increases (fig. 6A). At each site, we assume that the impact of water stress is acting upon the isotopic composition of soil $\mathrm{CO}_{2}$, with an effect of 1.5 permil (Wittmer and others, 2008). We also assume that there is a small component of $\mathrm{C}_{4}$ plants that accounts for approximately 1 permil of $\delta^{13} \mathrm{C}$ change. Further, declining $\mathrm{pCO}_{2}$ during the Oligocene will tend to decrease $\delta^{13} \mathrm{C}$ (fig. $6 \mathrm{~B}$ ). Thus, the difference between these three effects and the observed $\Delta \delta^{13} \mathrm{C}$ is driven by decreases in SR. At Taatsin Gol and Biger Noor, where our records tentatively span the Oligocene, decreases in SR must have been severe $(\sim 90 \%$ and $\sim 60 \%$ decrease, respectively) to offset the isotopic effect of declining $\mathrm{pCO}_{2}$. Similarly, at Dzereg, a $\sim 60$ percent decrease in SR is required to explain the full 5.5 permil shift. Thus, these results suggest a significant decrease in soil respiration and plant productivity in these basins.

Fourth, we can estimate changes in precipitation by relating SR to mean annual precipitation (MAP). Several studies have found an empirically linear relationship between SR and MAP, suggesting that a halving of MAP produces a 20 to 50 percent decrease in SR (table 2) (Raich and Schlesinger, 1992; Cotton and Sheldon, 2012). At Dzereg and Biger Noor, the 60 percent decrease in SR implies that MAP decreased from between 900 and $230 \mathrm{~mm}$ to $120 \mathrm{~mm}$ (the modern value at these sites). While these estimates are highly uncertain, they strongly suggest that MAP decreased remarkably at these sites. In modern Central Asia, this MAP decrease is equivalent to a $500 \mathrm{~km}$ shift from northern Mongolia or southern Siberia across the Altai and Hangay mountains (fig. A2 and Appendix 2). At Taatsin Gol, the even larger SR decrease 
TABLE 1

Parameters used in 1-D soil $\mathrm{CO}_{2}$ diffusion model to solve for soil respiration

\begin{tabular}{|c|c|c|c|c|}
\hline Parameter & Value & Units & Description & Source \\
\hline $10^{3} \ln \alpha$ & 10.02 & -- & $\begin{array}{l}\text { Fractionation factor } \\
\text { between calcite and } \mathrm{CO}_{2} \\
\text { at } 15^{\circ} \mathrm{C}\end{array}$ & Cerling (1999) \\
\hline $\mathrm{D}_{\text {air }}$ & 0.14 & $\mathrm{~cm}^{2} / \mathrm{s}$ & $\begin{array}{l}\mathrm{CO}_{2} \text { diffusion coefficient } \\
\text { in air }\end{array}$ & $\begin{array}{l}\text { Cerling and Quade } \\
\text { (1993) }\end{array}$ \\
\hline$\varepsilon$ & 0.5 & -- & Free-air porosity & $\begin{array}{l}\text { Cerling and Quade } \\
\text { (1993) }\end{array}$ \\
\hline$\rho$ & 0.6 & -- & Tortuosity & $\begin{array}{l}\text { Barnes and Allison } \\
\text { (1983) }\end{array}$ \\
\hline$D_{s}$ & $\mathrm{D}_{\mathrm{air}} \times \sum \times \rho$ & $\mathrm{cm}^{2} / \mathrm{s}$ & $\begin{array}{l}\mathrm{CO}_{2} \text { diffusion coefficient } \\
\text { in soil }\end{array}$ & $\begin{array}{l}\text { Cerling and Quade } \\
\text { (1993) }\end{array}$ \\
\hline$\delta_{\text {atm }}$ & -6.5 & -- & $\begin{array}{l}\text { Pre-industrial } \\
\text { atmospheric } \mathrm{CO}_{2} \text { isotopic } \\
\text { composition }\end{array}$ & $\begin{array}{l}\text { Tipple and others } \\
(2010)\end{array}$ \\
\hline$\delta_{\theta}$ & -27 & -- & $\begin{array}{l}\text { Soil-respired } \mathrm{CO}_{2} \\
\text { isotopic composition }\end{array}$ & Kohn (2010) \\
\hline $\mathrm{L}$ & 100 & $\mathrm{~cm}$ & Modeled depth of soil & \\
\hline $\mathrm{z}$ & 50 & & Depth in soil & \\
\hline$\theta$ & $\theta=\mathrm{SR} / \mathrm{L}$ & moles $/ \mathrm{cm}^{3} / \mathrm{s}$ & $\begin{array}{l}\text { Soil } \mathrm{CO}_{2} \text { Production } \\
\text { (constant with depth) }\end{array}$ & Cerling (1984) \\
\hline $\mathrm{C}_{\mathrm{atm}}$ & Variable & moles $/ \mathrm{cm}^{3}$ & $\begin{array}{l}\text { Cenozoic atmospheric } \\
\mathrm{pCO}_{2}\end{array}$ & $\begin{array}{l}\text { Beerling and Royer } \\
\text { (2011); Bartoli and } \\
\text { others (2011); } \\
\text { Foster and others } \\
\text { (2012); Zhang and } \\
\text { others (2013) }\end{array}$ \\
\hline
\end{tabular}

suggests an even more dramatic decrease in MAP of at least $1000 \mathrm{~mm}$. Because Cotton and Sheldon (2012) restrict their MAP-SR empirical relationship to carbonate forming soils, we suggest that the estimates produced using this relationship are more realistic. However, the $\delta^{13} \mathrm{C}$ increases at each site strongly suggest a severe decline in SR and plant productivity, driven by decreasing MAP.

Multiple complicating factors increase the uncertainty of these estimates. First, there are multiple soil parameters-such as porosity and tortuosity-that can change through time, but are poorly constrained at our sections. These both affect the diffusion coefficient $\left(\mathrm{D}_{\mathrm{s}}\right)$ and can alter the infiltration of atmospheric $\mathrm{CO}_{2}$. Second, declining precipitation tends to shallow the depth $(\mathrm{z})$ at which soil carbonate forms (Retallack, 2005), which would accentuate the observed $\delta^{13} \mathrm{C}$ increases. However, if carbonate formation shallowed upsection, one would expect synchronous increases in $\delta^{18} \mathrm{O}$ upsection, as soil carbonate $\delta^{18} \mathrm{O}$ increases with decreasing depth of carbonate formation (Quade and others, 1989; Cerling and Quade, 1993; Quade and others, 2011). The lack of corresponding increases in $\delta^{18} \mathrm{O}$ at all locations suggests that shallowing of carbonate formation was minimal. Third, decreasing soil temperature over the Neogene could measurably increase the $\delta^{13} \mathrm{C}$ of soil carbonate by changing the fractionation factor; however, changes in soil temperature during seasons of soil carbonate formation are unconstrained in Mongolia, with some modeling studies suggesting an increase in summertime temperature over the past $30 \mathrm{Ma}$ (Fluteau and others, 1999). Similarly, if temperatures were changing sufficiently to drive changes in 

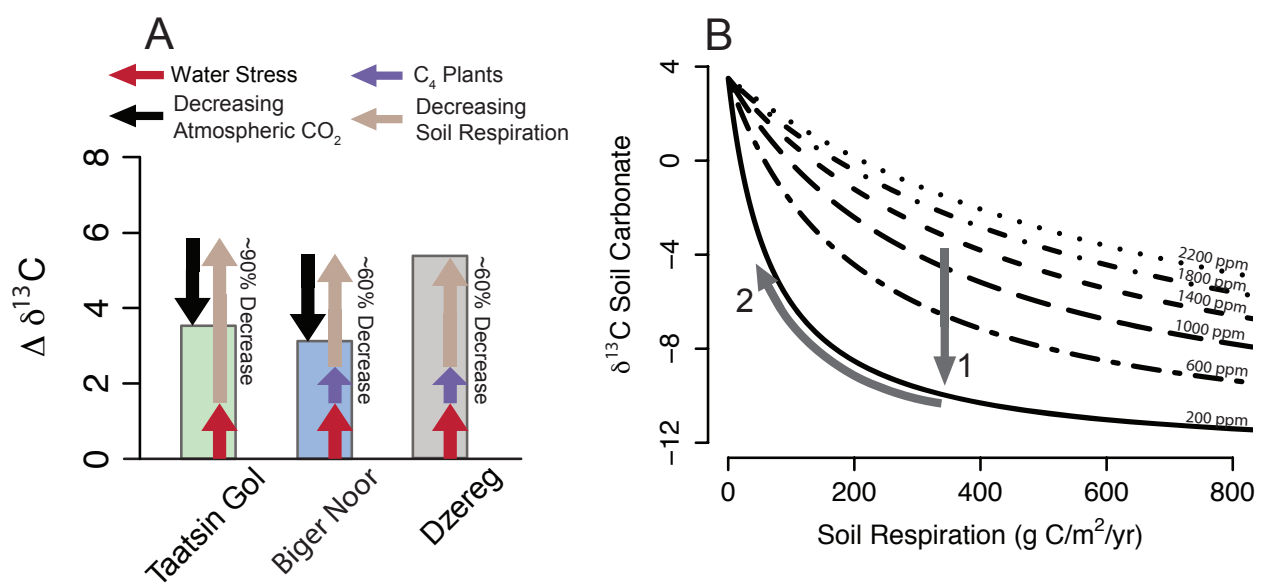

Fig. 6. (A) Effects of water stress, expansion of $\mathrm{C}_{4}$ plants, declining atmospheric pCO $\mathrm{O}_{2}$, and decreasing soil respiration on changes in soil carbonate $\delta^{13} \mathrm{C}$. Bar is the cumulative change in $\delta^{13} \mathrm{C}\left(\Delta \delta^{13} \mathrm{C}\right)$ over the length of the section. Arrows indicate effects of deconvolved factors on soil carbonate $\delta^{13} \mathrm{C}$. Water stress and $\mathrm{C}_{4}$ plant expansion are treated as constant effects of $1.5 \%$ and $1 \%$, respectively. Effect of declining atmospheric $\mathrm{CO}_{2}$ is calculated at constant SR. Thus, the difference between these three effects and $\Delta \delta^{13} \mathrm{C}$ is due to decreasing SR. The soil respiration decrease (in \%) required to explain the observed $\Delta \delta^{13} \mathrm{C}$ is listed beside each bar. (B) Illustration of the opposing effects of declining atmospheric $\mathrm{pCO}_{2}$ (arrow 1) and decreasing soil respiration (arrow 2) on soil carbonate $\delta^{13} \mathrm{C}$ at $50 \mathrm{~cm}$ soil depth assuming constant soil-respired $\mathrm{CO}_{2}$ production with depth (and same parameter values as in table 1). Curves are soil carbonate $\delta^{13} \mathrm{C}$ at a given atmospheric $\mathrm{CO}_{2}$ level against soil respiration $\left(\mathrm{g} \mathrm{C} / \mathrm{m}^{2} / \mathrm{yr}\right)$.

\section{TABLE 2}

Estimated precipitation decrease for each site given two different empirical relationships of soil respiration (SR) and mean annual precipitation (MAP). The following numbers assume that the entirety of the SR decrease is attributable to decreasing MAP with no contribution from increasing evaporation. Because Cotton and Sheldon (2012) restrict their analysis to carbonate-forming soils, we view estimates using their relationship as more realistic

\begin{tabular}{|c|c|c|c|c|c|c|}
\hline MAP-SR Relationship & \multicolumn{3}{|c|}{$\begin{array}{c}\text { Estimated \% SR Decrease } \\
\text { (fig. 6A) }\end{array}$} & \multicolumn{3}{|c|}{$\begin{array}{c}\text { Estimated MAP Decrease } \\
(\mathrm{mm})\end{array}$} \\
\hline $\begin{array}{l}\text { Units: } \\
\text { SR (gC/m²/yr); MAP (mm) }\end{array}$ & $\begin{array}{c}\text { Taatsin } \\
\text { Gol }\end{array}$ & $\begin{array}{l}\text { Biger } \\
\text { Noor }\end{array}$ & Dzereg & $\begin{array}{c}\text { Taatsin } \\
\text { Gol }\end{array}$ & $\begin{array}{l}\text { Biger } \\
\text { Noor }\end{array}$ & Dzereg \\
\hline $\begin{array}{l}\text { Raich and Schlesinger (1992) } \\
\mathrm{SR}=0.39 \times \mathrm{MAP}+155\end{array}$ & 90 & 60 & 60 & 4900 & 780 & 780 \\
\hline $\begin{array}{l}\text { Cotton and Sheldon }(2012)^{1} \\
S R=0.98( \pm 0.17) \times \text { MAP }-47\end{array}$ & 90 & 60 & 60 & 950 & 110 & 110 \\
\hline
\end{tabular}

${ }^{1}$ Cotton and Sheldon (2012) report data as soil-respired $\mathrm{pCO}_{2}$ below $30 \mathrm{~cm}$ soil depth. We convert their data to soil respiration rates assuming constant soil $\mathrm{CO}_{2}$ production with depth as given by

$$
S R=\frac{D_{s} \times S(z)}{\left(L z \frac{z^{2}}{2}\right)} \times L \quad(\text { Cerling, 1984) }
$$

where $\mathrm{S}(\mathrm{z})$ is the concentration of soil-respired $\mathrm{CO}_{2}$ below $30 \mathrm{~cm}$ soil depth $\left(\mathrm{mols} / \mathrm{cm}^{3}\right.$ ) (Cotton and Sheldon, 2012). 
$\delta^{13} \mathrm{C}$, one would expect to see correlated changes in $\delta^{18} \mathrm{O}$ in section, which is not observed. Fourth, increasing aridity can be driven by both declining precipitation and increasing evaporation. In the above calculations, we have attributed all aridity increases to decreasing MAP; any increase in evaporation will reduce our MAPdecrease estimates. For instance, the Altai and Hangay not only create a rain shadow, but also block cool, moist Siberian air from flowing south. As a result, evaporation likely increased with simultaneous decreases in MAP due to Altai and Hangay uplift.

In summary, the increases in $\delta^{13} \mathrm{C}$ observed at all three sections indicate a decrease in productivity due to an increase in aridity. However, this aridity was diachronous and spread westward and northward. First, Taatsin Gol and Biger Noor experienced a decline in biomass production during the Oligocene, likely linked to a decrease in precipitation and an increase in evaporation, and this trend continued into the Miocene. During the late Miocene and Pliocene, Dzereg and Biger Noor experienced further increases in aridity, shifting the boundary between the Gobi and the boreal forest northward.

\section{$\delta^{18} \mathrm{O}$ Record}

Epoch-level grouping of $\delta^{18} \mathrm{O}$ data shows no statistical difference either among sites or epochs; however, within individual sections, trends in $\delta^{18} \mathrm{O}$ are apparent (figs. 4 and 5). The early to mid-Miocene increase in $\delta^{18} \mathrm{O}$ at Dzereg follows the pan-Asian and global trend of increasing $\delta^{18} \mathrm{O}$ since the Miocene (Dettman and others, 2003; Kent-Corson and others, 2009; Zhuang and others, 2011; Charreau and others, 2012; Mix and others, 2013). However, during the late Miocene and Pliocene, Dzereg $\delta^{18} \mathrm{O}$ values remain approximately constant at 20.6 permil. This change from increasing to constant $\delta^{18} \mathrm{O}$ values diverges from the global $\delta^{18} \mathrm{O}$ trend and correlates in-section with an increase in $\delta^{13} \mathrm{C}$, which we have attributed to aridification. Our HYSPLIT results reveal that moisture transport to Dzereg is strongly influenced by the modern elevation of the Altai. Orographic forcing over and around the Altai produces $\delta^{18} \mathrm{O}$-enriched rainfall on the windward side of the Altai, and as a consequence, ${ }^{18} \mathrm{O}$-depleted vapor is advected across Mongolia (Sato and others, 2007). Thus, we tentatively interpret the constant $\delta^{18} \mathrm{O}$ at Dzereg and the departure from the pan-Asian/global trend of increasing $\delta^{18} \mathrm{O}$ as a result of uplift of the Altai. Further, increased aridity in the lee of the Altai should drive increased evaporation, increasing $\delta^{18} \mathrm{O}$ and potentially offsetting the effect of ${ }^{18} \mathrm{O}$-depleted vapor forming over the Altai. Constant $\delta^{18} \mathrm{O}$ of 20.5 permil and 21.6 permil at Biger Noor and Taatsin Gol is more difficult to explain, but perhaps reflects overall constant westerly moisture with ${ }^{18} \mathrm{O}$-depleted vapor forming over the Hangay and Altai being offset by increasingly arid conditions in the northern Gobi.

\section{East to West Growth of Topography in Mongolia}

Our results are suggestive of an east to west growth of topography that progressively blocked moisture to each of these basins. The increase in $\delta^{13} \mathrm{C}$ during the Oligocene at Taatsin Gol and Biger Noor indicates that the Hangay began to rise by the early Oligocene, while the Altai began uplifting in the late Miocene, driving increased aridity at Dzereg and exacerbating aridity at Biger Noor.

An Oligocene age for the onset of uplift in the Hangay supports fault-mapping (Cunningham, 2001) and sedimentary studies (Höck and others, 1999) from the southern Hangay that found evidence for uplift in the Oligocene and continual north-to-south drainage throughout the Oligocene and Miocene. Further, Jolivet and others (2013) noted both geomorphic and AFT evidence for a broad wavelength uplift in the Sayan during the Oligocene and early Miocene. However, a transition between 7 to $2 \mathrm{Ma}$ from plateau-style to valley-filling basalts on the northern slopes of the Hangay were argued to support a younger age for the Hangay, making the Hangay synorogenic with proposed uplifts for the Altai (Yarmolyuk and others, 2008). We 
speculate instead that this transition represents greater erosion in the northern Hangay due to Siberia-sourced precipitation, consistent with the inferences of West and others (2013) of greater erosion due to more precipitation in the northern Hangay.

The $\delta^{18} \mathrm{O}$ and $\delta^{13} \mathrm{C}$ records from Dzereg and Biger Noor point to a younger age of surface uplift-late Miocene through Pliocene-for the Altai. Surface uplift of the Altai would have blocked moisture from the west, producing increasingly arid conditions in the Valley of Lakes at Dzereg and Biger Noor and shifting precipitation to the windward slopes. These arid conditions are responsible for the $\delta^{13} \mathrm{C}$ increase in the late Neogene as well as the relative constancy of $\delta^{18} \mathrm{O}$ during the upper Miocene and Pliocene at both Dzereg and Biger Noor. Paleontological evidence from Dzereg further supports a drying since at least the Pliocene. Faunal assemblages from the early Pliocene are more similar to those found on the steppe and closer to the transition between the boreal forest and steppe (Borsuk-Bialynicka, 1969; Czyzewski, 1969), suggesting a wetter climate in the early Pliocene and a subsequent northward shift of subarctic biomes. In contrast, on the windward flanks of the Altai, the Kurai and Chuya basins contain abundant lacustrine facies from this same interval (Delvaux and others, 2013), indicating continued abundant moisture and the establishment of the Altai rain shadow. This estimate for Altai uplift corroborates, within uncertainty, age estimates from structural studies (Cunningham and others, 1996; Cunningham, 2005; Cunningham, 2010) and AFT ages (De Grave and others, 2007; Vassallo and others, 2007; Buslov and others, 2008; De Grave and others, 2009; Jolivet and others, 2013).

Most previous stable isotope studies in Central Asia have implicated either changing global/regional climate, Paratethys retreat, or progressive uplift of the Tibetan Plateau to explain their stable isotopic records (Dettman and others, 2003; Graham and others, 2005; Wang and Deng, 2005; Kent-Corson and others, 2009; Hough and others, 2011; Zhuang and others, 2011). By the early Oligocene, the Paratethys was likely $1000+\mathrm{km}$ to the west (Popov and others, 2004), making its influence on regional moisture difficult to discern. Further, while global cooling in the late Neogene undoubtedly influenced moisture transport globally, long-standing lakes on the windward flanks of the Altai (Delvaux and others, 2013) suggest that moisture transport to the Altai remained vigorous throughout the Neogene, and it is Altai topography that aridified Dzereg and Biger Noor. While we recognize that the Tibetan Plateau has a large influence on climate, the Himalayas and much of Tibet have been high since the Eocene (Rowley and Currie, 2006; Wang and others, 2008; Yuan and others, 2013; Ding and others, 2014), and may have blocked southern moisture flow since then (Boos and Kuang, 2010). Further, climate models suggest that the northern Gobi Desert should be only minimally impacted by subsidence caused by diabatic heating over the Tibetan Plateau (Sato and Kimura, 2005; Sato, 2009). Thus, we suggest that the Altai and Hangay have played an important role in modifying climate in northern Central Asia.

\section{Implications for Asian Tectonics and Climate}

Our results point to a diachronous uplift history for northern Central Asia, with the Hangay rising during the Oligocene, perhaps 20 million years before renewed tectonism in the Altai. Such a result suggests that models of progressive northward propagation of deformation associated with India-Asia convergence may explain the Altai, but cannot explain the Hangay. Instead, our results support the view that, beginning in the Oligocene, there was surface uplift of the Hangay (Cunningham, 2001; Jolivet and others, 2013) which blocked southward moisture transport. Our results from Biger Noor and Dzereg support earlier work that the Altai experienced renewed tectonism in the late Miocene and Pliocene (Vassallo and others, 2007; Buslov and others, 2008; De Grave and others, 2009; Delvaux and others, 2013) and that this 
tectonism was accompanied by surface orographic changes that blocked moisture transport into western and southwestern Mongolia.

Further, our results suggest that the Altai became high enough during the late Miocene to affect climate, expanding the Gobi Desert to the north and west. This renewed uplift may also explain changes seen across Central Asia in the late Miocene. As the largest source of cyclogenesis in Central Asia, the Altai are partially responsible for creating storms strong enough to entrain dust from the Gobi and deposit that dust on the Loess Plateau (Shao and Dong, 2006; Roe, 2009). Loess deposition on the Loess Plateau began as early as $22 \mathrm{Ma}$ (Guo and others, 2002), but significantly intensified in the late Miocene (Sun and others, 1998; Y. Sun and others, 2010). Beginning in the late Miocene, the Altai may have reached a sufficient height to intercept the westerlies and create abundant cyclones. An increase in cyclonic activity, combined with greater aridification due to the Altai rain shadow, would have entrained more dust, creating a thicker blanket of eolian deposits on the Loess Plateau during the late Miocene.

We note that our sections are only broadly dated and therefore correlations between climatic and tectonic events and our stable isotope records should be viewed as tentative. Yet, even when the results are binned by epoch (fig. 5), they suggest a substantial aridification that spread east to west and is broadly correlated with substantial changes across Central Asia. Thus, our results suggest that mountain chains to the north of the Tibetan Plateau have played a role in establishing widespread aridity in eastern Central Asia. The Altai and Hangay, in particular, form the northern boundary of this arid region, and shifted the transition between desert-steppe and boreal forest northward. Thus, the surface uplift histories of the Hangay and Altai are critical to understanding the evolution of aridity in eastern Central Asia.

\section{CONCLUSION}

To understand the role of the Altai and Hangay in establishing aridity in Central Asia, we present stable isotope data from the northernmost carbonate-bearing paleosol sections in Central Asia, collected across a $650 \mathrm{~km}$ swath on the northern and western edge of the Gobi desert. $\delta^{13} \mathrm{C}$ increases in all three studied basins during both the Oligocene and late Neogene, indicating significant decreases in primary productivity due to increases in aridity. In contrast, $\delta^{18} \mathrm{O}$ increases during the lower Miocene at Dzereg, but remains constant during the upper Miocene and Pliocene. We combine these results with HYSPLIT back-trajectory modeling to demonstrate modern regional moisture transport pathways, and show that the Hangay block southward moisture transport from Siberia, while the Altai force moisture-laden air parcels southeast through the Valley of Lakes or east over the southern Altai. As a consequence, we conclude that the Hangay are at least Oligocene in age, as demonstrated by increasing aridity at Taatsin Gol and Biger Noor during the Oligocene. In contrast, the Altai are significantly younger (late Miocene)-supporting results from AFT and structural studies - and have created a distinct rain shadow that blocks moisture from reaching western Mongolia. The rise of the Altai is reflected in increasing $\delta^{13} \mathrm{C}$ at Dzereg and Biger Noor in the upper Miocene through Pliocene and constant $\delta^{18} \mathrm{O}$. Thus, ranges well north of the Tibetan Plateau have had a marked influence on the creation of one of the largest and most arid regions on the planet.

ACKNOWLEDGMENTS

We thank Bayasgalan Amgalan, Chimgee Baldandorg, and Altan Baldan for considerable logistical help organizing our field work in Mongolia. In particular, we thank the many Mongolian drivers who schlepped us around Mongolia, our two translators (Ganaa Gatlaga and Otgontugs "Ogii" Eukhtuya), and our cook (Dagii) for contributing greatly to the success of our field excursions. We also thank Forrest Chamberlain, Noah Peart, Susannah Poland, and Jobe Traywick for field assistance. 
We further thank Peter Blisniuk, Walter Torres, and Alexis Wood for assistance in the lab, and Alex Lechler for help setting up HYSPLIT. Finally, we thank Carmala Garzione and an anonymous reviewer for comments that improved the quality of this paper. Funding for this project was provided by NSF grant EAR-1009721 to CPC and an NSF Graduate Research Fellowship and Stanford Graduate Fellowship to JKC.

Appendix 1

Evidence for Pedogenesis

Critical to the interpretation presented in this paper is the assumption that the carbonates sampled are of pedogenic origin. We provide five lines of evidence that suggest that all of the types of carbonate sampled (nodule, caliche, and interstitial) formed in a shallow, soil environment. First, all sections contain abundant evidence of root casts, mottled soils, and laterally extensive caliche layers that we and previous authors (Höck and others, 1999; Howard and others, 2003) interpret as pedogenic features (see also fig. A4). Second, two of our sections (Biger Noor and Dzereg) extend into the Quaternary, and the top samples collected represent a modern soil (that is, a soil currently exposed to weathering processes and hosting plants on the surface). These soils contain abundant interstitial calcite, which formed within 1 or 2 meters of the surface. At both Biger Noor and Dzereg, interstitial calcite becomes the dominant type of carbonate collected within these sections. The predominance of interstitial calcite in modern soils in Mongolia at the same locations as our sections suggests that the interstitial calcite collected lower in the section is also of pedogenic origin. Third, though we collected nodule and caliche calcite when exposed in the section, at most locations where we collected nodule and caliche calcite, interstitial calcite was also present. Fourth, in thin section, the interstitial carbonates within our samples appear finely and irregularly laminated, are reddish-brown in color, and have a subtle pisolitic texture. This suggests a pedogenic origin in a semi-arid or arid environment (Goudie and Pye, 1983). Fifth, there is no statistical difference in the $\delta^{18} \mathrm{O}$ value between nodule, caliche, and interstitial carbonates (see Results section), suggesting that all of these types of carbonate are forming in similar environments. Though we cannot rule out some of these samples forming in a non-pedogenic environment, we believe the above lines of evidence strongly indicate that the calcites presented in this study are of pedogenic origin.

Diagenetic Considerations

The diagenesis of pedogenic carbonates can significantly alter oxygen isotope ratios, and, to a lesser extent, the carbon isotope composition of carbonate (Dickson and Coleman, 1980). We exclude diagenesis as affecting these sections due to the shallow burial depth of these sediments. Traynor and Sladen (1995), in a survey of the stratigraphic evolution of Mongolia, concluded that late Cretaceous and Cenozoic sediments constitute a thin veneer over thicker Jurassic and early Cretaceous sediments, with thicknesses rarely greater than $500 \mathrm{~m}$. Our field observations confirm this conclusion. Both Biger Noor and Dzereg are capped by Quaternary alluvium, indicating that the thicknesses measured in our sections are likely the actual maximum thickness experienced by these sediments. Though our Taatsin Gol sections are not capped by Quaternary alluvium, this is likely due to non-deposition rather than later erosion (Höck and others, 1999). Additionally, petrographic examination of samples collected at each site revealed no development of pseudo-matrix or secondary porosity that might be suggestive of extensive diagenesis.

We confirmed the lack of detrital carbonate by conducting petrographic examination of thin-sections on our samples from all three sites. The clasts consist exclusively of siliciclastic compositions. Additionally, Howard and others (2003) noted only small amounts of detrital limestone in the Pliocene at Dzereg, while Höck and others (1999) noted negligible amounts of detrital carbonate at Taatsin Gol. 


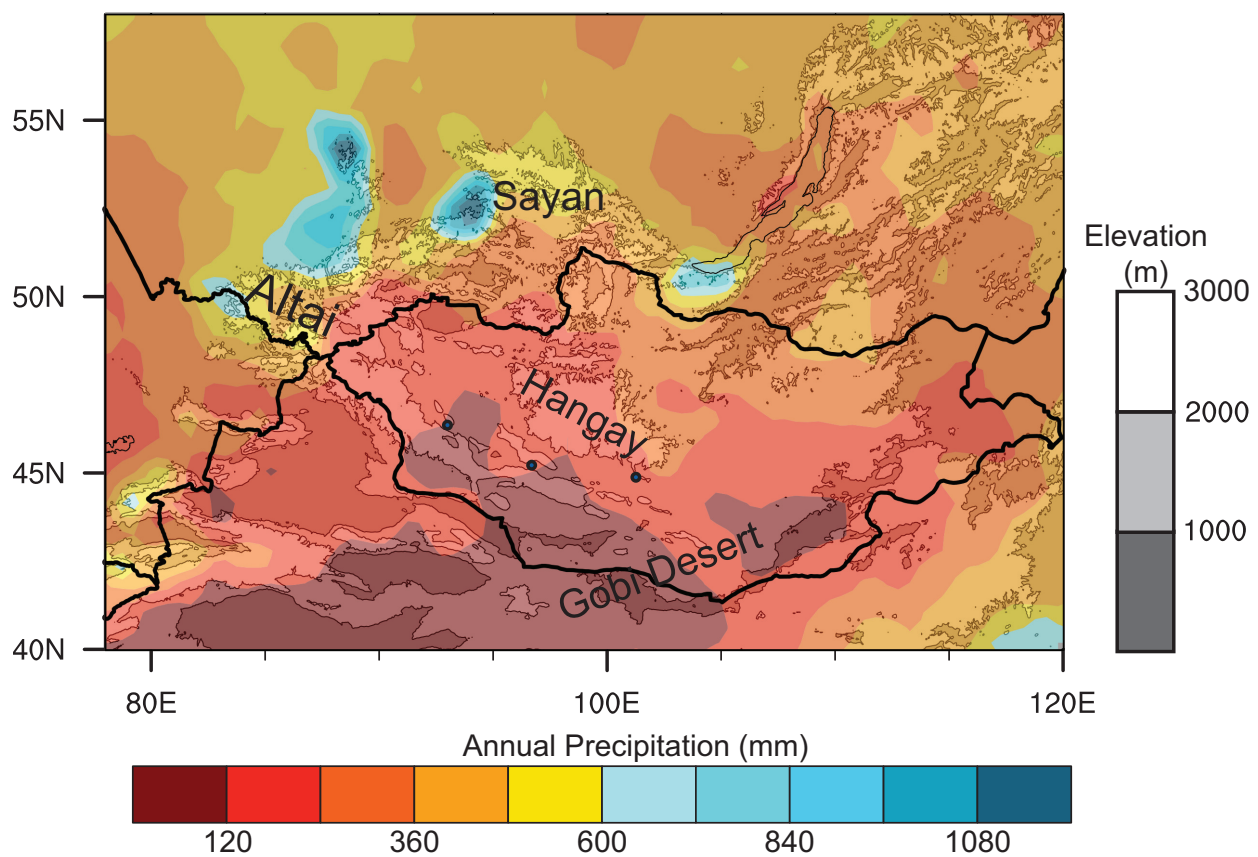

Fig. A2. Map of average annual precipitation (1901-2010), compiled by the Global Precipitation Climatology Centre (Schneider and others, 2011), at $0.5^{\circ}$ by $0.5^{\circ}$ resolution overlaid on topography. The studied basins (blue circles) are located in basins with $150 \mathrm{~mm}$ or less annual precipitation. 
APPENDix 3

Additional HYSPLIT Results for the Northern Hangay
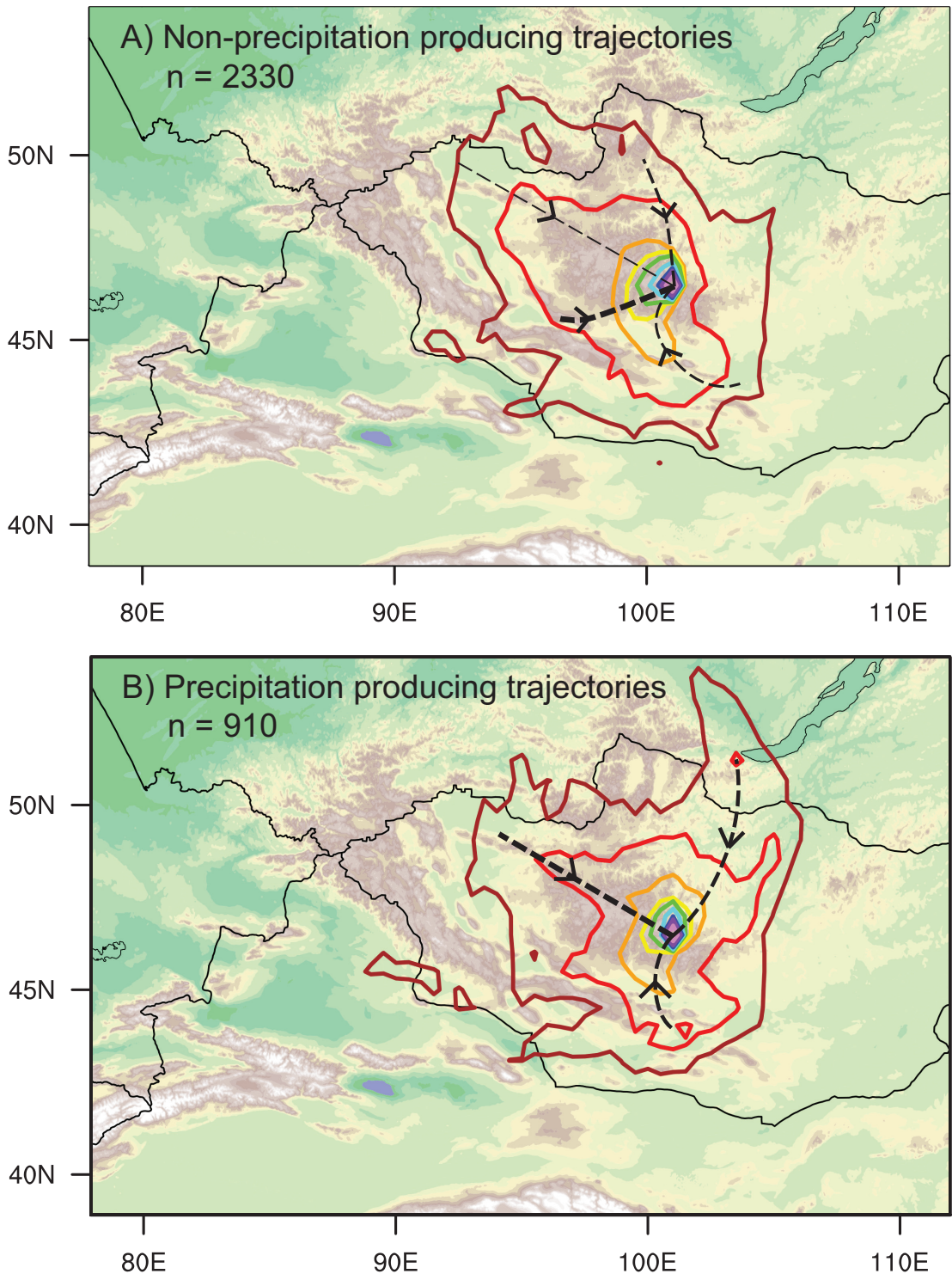

$\%$ of Precipitation Trajectories

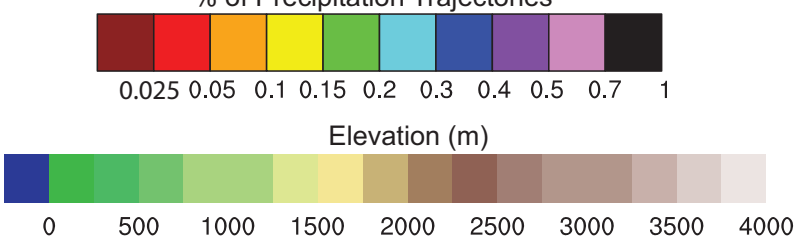

Fig. A3. Contour plots of non-precipitation producing trajectories (A) and precipitation producing trajectories (B) at the site on the northern flanks of the Hangay. Note the prominent group of trajectories traveling south from Siberia in (B) that is absent in (A). Trajectories are binned by $0.5^{\circ}$ by $0.5^{\circ}$ to produce contours. Dashed lines are approximate mean trajectory routes, with arrows showing direction of travel. Thickness of the dashed line approximately corresponds to percentage of trajectories represented by the mean trajectory. 

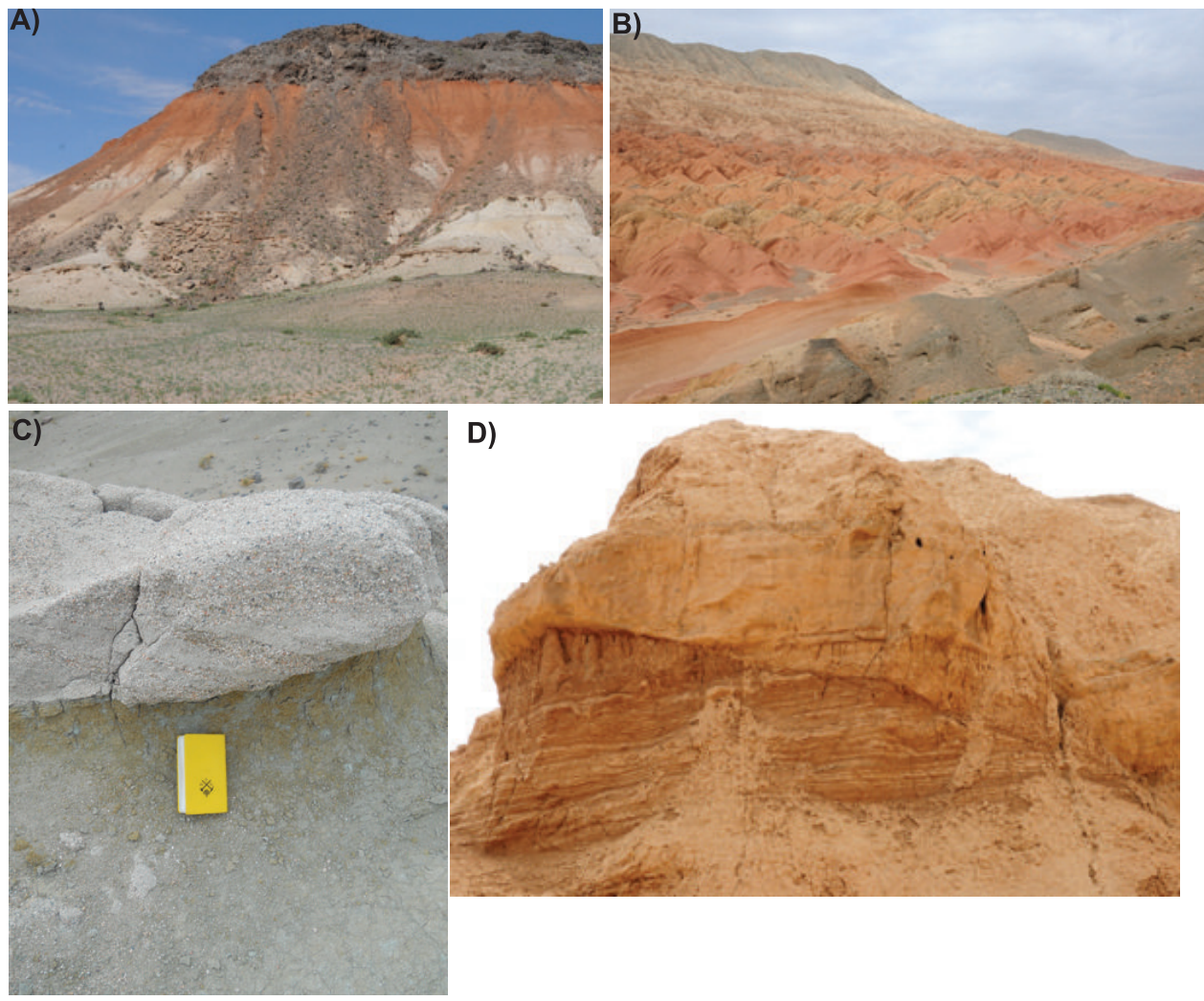

Fig. A4. (A) Outcrop scale photograph of the lowermost section at Taatsin Gol. Lowest-most white sediments are aridisols comprising the Tsaagan Ovoo Fm; overlying red sediments are the fossil-rich Hsanda Gol Fm., and the capping basalt is $31 \mathrm{Ma}$. Height of outcrop is approximately $25 \mathrm{~m}$. (B) Outcrop-scale photograph of the Biger Noor section. Red sediments are Oligocene and thought to be correlative with the Taatsin Gol Hsanda Gol Fm. (Gradzinski and others, 1969; Devyatkin, 1981); Overlying white sediments are Miocene aridisols and grayish capping sediments are Pliocene-Quaternary. (C) Typical paleosol sequence in the lower Miocene at Dzereg: Clay-rich paleosol (aridisol) overlain by sandy fluvial channel. A discontinuous caliche layer is seen as whiter sediments beneath field notebook. (D) Miocene channel at Biger Noor cutting into fine-grained overbank deposits; nodules visible near the top of the overbank deposits forming in aridisol. Outcrop height is approximately $3 \mathrm{~m}$. 
APPENDix 5

Atmospheric $\mathrm{CO}_{2}$ Compilation

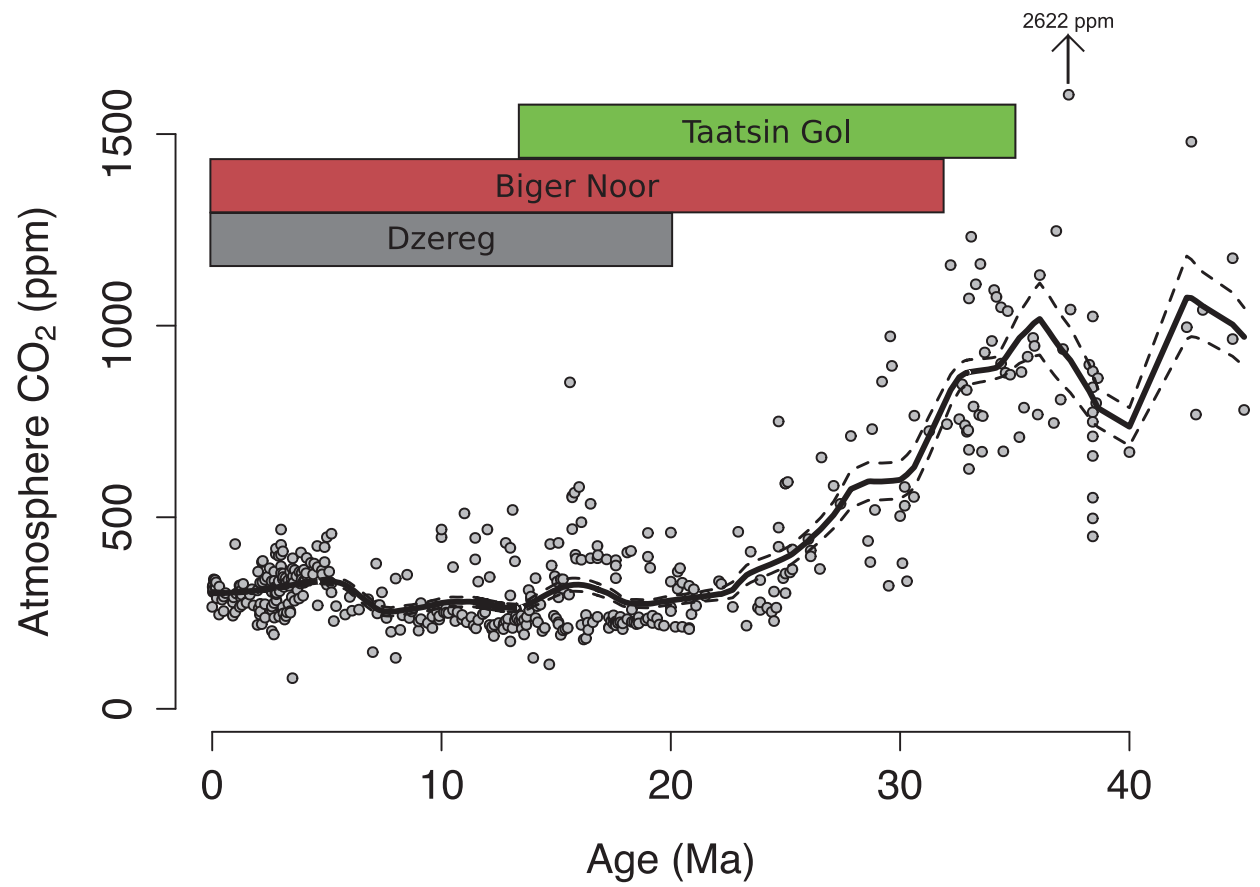

Fig. A5. Compilation of atmospheric $\mathrm{CO}_{2}$ proxies (Bartoli and others, 2011; Beerling and Royer, 2011; Foster and others, 2012; Zhang and others, 2013) used to constrain $\mathrm{C}_{\mathrm{atm}}$ in the 1-D soil CO diffusion model. Thick black line is the $1 \mathrm{Ma}$ Epanechnikov kernel smooth of the data and thin, dashed lines are standard error of the kernel smooth. Boxes show approximate span of ages for each of the three sections presented in the main text. 

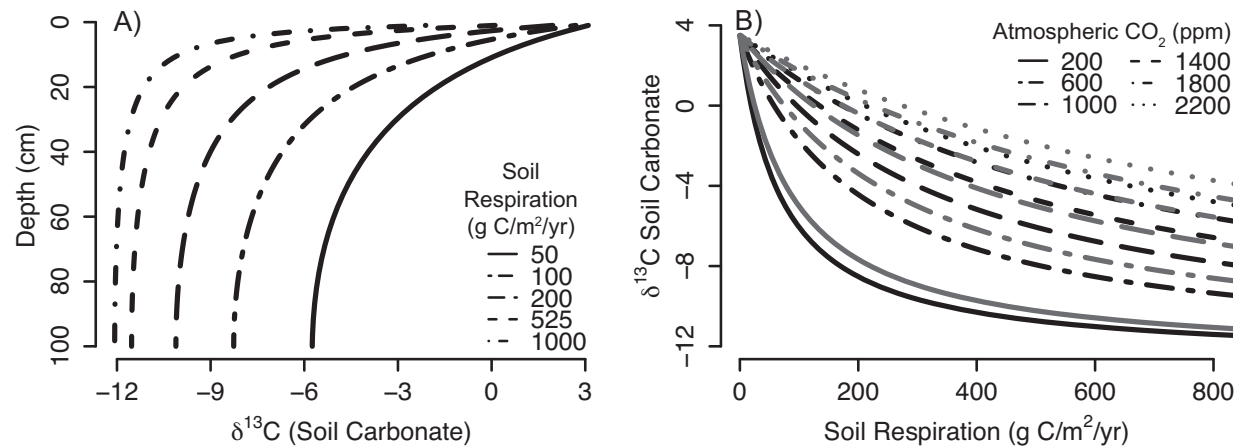

Fig. A6. (A) $\delta^{13} \mathrm{C}$ of soil carbonate against depth at various soil respiration levels $\left[50 \mathrm{~g} / \mathrm{m}^{2} / \mathrm{yr}\right.$ corresponds to a desert and $1000 \mathrm{~g} / \mathrm{m}^{2} / \mathrm{yr}$ corresponds to a tropical forest (Raich and Schlesinger, 1992)]. Calculated using pre-industrial atmospheric $\mathrm{CO}_{2}$ of $280 \mathrm{ppm}$, a temperature of $15^{\circ} \mathrm{C}$, and parameters listed in table 2. (B) Effect of a $20 \mathrm{~cm}$ shallowing of carbonate formation on $\delta^{13} \mathrm{C}$. Black lines are calculated using $50 \mathrm{~cm}$ depth of soil carbonate formation (as in fig. 6B, main text), while gray lines are calculated assuming a $30 \mathrm{~cm}$ depth of formation.

In the main text, we assume that the sampled soil carbonate formed at a depth (z) of $50 \mathrm{~cm}$. Because tops of paleosols were poorly exposed and typically eroded by overlying fluvial deposits or obscured by modern weathering processes, we cannot constrain with absolute certainty the depth of soil carbonate formation. Therefore, here we present an analysis to constrain the sensitivity of our soil respiration estimates to changing depth (z) of carbonate formation.

First, figure A6A shows how the $\delta^{13} \mathrm{C}$ of soil carbonate varies with depth across a range of soil respiration (SR) values. At the low estimated SR for our sections, the $\delta^{13} \mathrm{C}$ of soil carbonate is sensitive to the depth of formation, particularly above $50 \mathrm{~cm}$. However, we note that to explain the entire $5.5 \%$ increase in $\delta^{13} \mathrm{C}$ observed at Dzereg simply by shallowing soil carbonate formation requires a decrease in the depth of carbonate formation of approximately 30 to $40 \mathrm{~cm}$. Such a dramatic shallowing of carbonate formation should also be reflected in increasing $\delta^{18} \mathrm{O}$, as soil water $\delta^{18} \mathrm{O}$ increases with decreasing depth due to evaporative effects; yet, this is not observed in any section.

Second, figure A6B shows how a $20 \mathrm{~cm}$ shallowing of carbonate formation (from $50 \mathrm{~cm}$ to $30 \mathrm{~cm}$ ) affects soil carbonate $\delta^{13} \mathrm{C}$ at a given SR. At the low SR estimated for our sites, a $20 \mathrm{~cm}$ shallower carbonate formation results in up to $2 \%$ increase in $\delta^{13} \mathrm{C}$. While this potentially contributes to increasing $\delta^{13} \mathrm{C}$ at our sites, it cannot explain the full increase in $\delta^{13} \mathrm{C}$ at any of our sites. 
APPENDix 7

TABLE A7

$\delta^{18} O$ and $\delta^{13} C$ data

\begin{tabular}{|c|c|c|c|c|c|c|}
\hline Sample ID & Height (m) & $\begin{array}{l}\text { Assigned } \\
\text { Age (Ma) } \\
\end{array}$ & Epoch & $\delta^{18} \mathrm{O}$ & $\delta^{13} \mathrm{C}$ & Sample Type \\
\hline \multicolumn{7}{|c|}{ Dzereg $(47.1387 N 93.0598 E)$} \\
\hline D31 & 0 & 20.0 & Miocene & -12.81 & -8.01 & sandstone \\
\hline $\mathrm{D} 32$ & 1 & 19.9 & Miocene & -11.6 & -9.27 & carbonate nodule \\
\hline $\mathrm{D} 33$ & 9 & 18.9 & Miocene & -11.56 & -9.06 & carbonate nodule \\
\hline D34 & 13 & 18.5 & Miocene & -11.6 & -9.76 & carbonate nodule \\
\hline D35 & 15 & 18.2 & Miocene & -10.98 & -8.38 & carbonate nodule \\
\hline D37 & 18 & 17.9 & Miocene & -11.04 & -8.50 & caliche \\
\hline D36 & 19 & 17.8 & Miocene & -10.57 & -7.12 & carbonate nodule \\
\hline D38 & 23 & 17.3 & Miocene & -11.42 & -6.25 & sandstone \\
\hline D40 & 28 & 16.7 & Miocene & -9.69 & -8.41 & carbonate nodule \\
\hline D41 & 36 & 15.8 & Miocene & -10.85 & -9.45 & caliche \\
\hline D42 & 39 & 15.4 & Miocene & -10.91 & -9.54 & caliche \\
\hline D43 & 43 & 15.0 & Miocene & -8.93 & -8.89 & carbonate nodule \\
\hline D44 & 46 & 14.6 & Miocene & -10.3 & -8.6 & caliche \\
\hline D45 & 47 & 14.5 & Miocene & -10.56 & -7.38 & caliche \\
\hline D46 & 50 & 14.1 & Miocene & -10.49 & -8.89 & caliche \\
\hline D47 & 54 & 13.7 & Miocene & -10.8 & -10.06 & caliche \\
\hline $\mathrm{D} 48$ & 58 & 13.2 & Miocene & -10.15 & -8.29 & caliche \\
\hline D49 & 64 & 12.5 & Miocene & -10.08 & -9.15 & caliche \\
\hline D50 & 66 & 12.3 & Miocene & -9.93 & -8.23 & caliche \\
\hline D51 & 68 & 12.0 & Miocene & -10.68 & -10.02 & caliche \\
\hline D53 & 83 & 10.3 & Miocene & -10.03 & -8.94 & caliche \\
\hline D54 & 86 & 9.9 & Miocene & -10.36 & -8.46 & caliche \\
\hline D55 & 88 & 9.7 & Miocene & -10.51 & -8.3 & caliche \\
\hline D56 & 94 & 9.0 & Miocene & -10.34 & -6.78 & carbonate nodule \\
\hline D57 & 109 & 7.2 & Miocene & -9.37 & -5.37 & caliche \\
\hline D58 & 118 & 6.2 & Miocene & -10.22 & -6.23 & caliche \\
\hline D59 & 120 & 5.9 & Miocene & -10.33 & -6.8 & caliche \\
\hline D60 & 122 & 5.7 & Miocene & -7.51 & -4.62 & sandstone \\
\hline D61 & 124 & 5.5 & Miocene & -9.57 & -6.38 & carbonate nodule \\
\hline D62 & 126 & 5.2 & Miocene & -9.96 & -6.58 & caliche \\
\hline D63 & 128 & 5.0 & Miocene & -9.57 & -6.14 & caliche \\
\hline D64 & 140 & 4.1 & Pliocene & -10.13 & -6.34 & silt \\
\hline D65 & 142 & 4.0 & Pliocene & -9.87 & -5.79 & sandstone \\
\hline D66 & 143 & 3.9 & Pliocene & -9.74 & -6.13 & sandstone \\
\hline D67 & 143 & 3.9 & Pliocene & -10.06 & -6.74 & sandstone \\
\hline D68 & 159 & 2.8 & Pliocene & -9.69 & -5.65 & sandstone \\
\hline D69 & 164 & 1.9 & Quaternary & -11.10 & -5.97 & conglomerate \\
\hline D71 & 179 & 0.9 & Quaternary & -10.14 & -3.91 & conglomerate \\
\hline D72 & 189 & 0.0 & Quaternary & -8.62 & -2.67 & conglomerate \\
\hline \multicolumn{7}{|c|}{ Biger Noor (45.8965N 96.7756E) } \\
\hline BB1 & 0 & 30.0 & Oligocene & -10.48 & -4.42 & pebble conglomerate \\
\hline BB2 & 3 & 29.8 & Oligocene & -9.63 & -5.4 & carbonate-rich silt \\
\hline BB3 & 6 & 29.6 & Oligocene & -9.27 & -4.25 & carbonate-rich silt \\
\hline BB5 & 12 & 29.1 & Oligocene & -10.03 & -5.49 & carbonate-rich silt \\
\hline BB6 & 12 & 29.1 & Oligocene & -8.5 & -6.4 & carbonate nodule \\
\hline BB7 & 13.5 & 29.0 & Oligocene & -10.92 & -8.3 & pebble conglomerate \\
\hline BB16 & 34.5 & 27.5 & Oligocene & -9.89 & -4.87 & sandstone \\
\hline BB22 & 47 & 26.6 & Oligocene & -9.05 & -5.28 & carbonate-rich silt \\
\hline BB23 & 48 & 26.5 & Oligocene & -9.34 & -5.06 & carbonate-rich silt \\
\hline BB24 & 50.5 & 26.4 & Oligocene & -9.23 & -4.54 & carbonate-rich silt \\
\hline
\end{tabular}


TABLE A7

(continued)

\begin{tabular}{|c|c|c|c|c|c|c|}
\hline Sample ID & Height (m) & $\begin{array}{l}\text { Assigned } \\
\text { Age (Ma) }\end{array}$ & Epoch & $\delta^{18} \mathrm{O}$ & $\delta^{13} \mathrm{C}$ & Sample Type \\
\hline \multicolumn{7}{|c|}{ Biger Noor (45.8965N 96.7756E) } \\
\hline BB26 & 62 & 25.5 & Oligocene & -9.4 & -4.11 & sandstone \\
\hline BB28 & 66.5 & 25.2 & Oligocene & -11.25 & -4.67 & carbonate-rich silt \\
\hline BB29 & 68.5 & 25.1 & Oligocene & -9.93 & -4.34 & carbonate-rich silt \\
\hline BB31 & 73 & 24.7 & Oligocene & -8.75 & -3.63 & carbonate-rich silt \\
\hline BB32 & 74 & 24.7 & Oligocene & -8.61 & -4.06 & pebble conglomerate \\
\hline BB33 & 75.5 & 24.6 & Oligocene & -11.09 & -2.54 & sandstone \\
\hline BB34 & 77.5 & 24.4 & Oligocene & -10.05 & -3.48 & carbonate-rich silt \\
\hline BB35 & 78.5 & 24.3 & Oligocene & -9.21 & -4.26 & carbonate-rich silt \\
\hline BB36 & 80 & 24.2 & Oligocene & -10.18 & -4.37 & sandstone \\
\hline BB37 & 81 & 24.2 & Oligocene & -9.14 & -5.78 & carbonate-rich silt \\
\hline BB38 & 82 & 24.1 & Oligocene & -11.6 & -4.64 & carbonate-rich silt \\
\hline BB39 & 84 & 23.9 & Oligocene & -9.86 & -3.90 & pebble conglomerate \\
\hline BB41 & 89.5 & 23.5 & Oligocene & -9.99 & -3.47 & sandstone \\
\hline BB44 & 94 & 23.2 & Oligocene & -9.95 & -5.17 & sandstone \\
\hline BB46 & 97 & 23.0 & Oligocene & -11.22 & -5.01 & sandstone \\
\hline BB47 & 98 & 22.5 & Miocene & -9.11 & -4.62 & sandstone \\
\hline BB48 & 99 & 22.1 & Miocene & -9.23 & -6.96 & carbonate-rich silt \\
\hline BB49 & 100.5 & 21.3 & Miocene & -6.45 & -3.70 & carbonate-rich silt \\
\hline BB50 & 104.5 & 19.4 & Miocene & -9.44 & -6.15 & sandstone \\
\hline BB52 & 106.5 & 18.5 & Miocene & -11.99 & -6.13 & carbonate nodule \\
\hline BB53 & 107.5 & 18.0 & Miocene & -10.09 & -5.52 & carbonate nodule \\
\hline BB54 & 110 & 16.8 & Miocene & -12.17 & -4.32 & sandstone \\
\hline BB55 & 113 & 15.4 & Miocene & -10.36 & -4.74 & sandstone \\
\hline BB56 & 113.5 & 15.2 & Miocene & -10.84 & -5.09 & sandstone \\
\hline BB57 & 114.5 & 14.7 & Miocene & -10.61 & -5.37 & sandstone \\
\hline BB58 & 116 & 14.0 & Miocene & -9.59 & -5.08 & sandstone \\
\hline BB59 & 118 & 13.1 & Miocene & -8.81 & -4.62 & sandstone \\
\hline BB60 & 119 & 12.6 & Miocene & -5.93 & -3.56 & sandstone \\
\hline BB61 & 121 & 11.6 & Miocene & -11.69 & -4.19 & sandstone \\
\hline BB63 & 123 & 10.7 & Miocene & -10.31 & -2.99 & sandstone \\
\hline BB66 & 130.5 & 7.1 & Miocene & -7.9 & -3.86 & sandstone \\
\hline BB67 & 132 & 6.4 & Miocene & -10.37 & -3.09 & sandstone \\
\hline BB68 & 133.5 & 5.7 & Miocene & -10.05 & -2.91 & sandstone \\
\hline BB70 & 137 & 4.8 & Pliocene & -9.52 & -3.59 & carbonate-rich silt \\
\hline BB71 & 139 & 4.6 & Pliocene & -10.28 & -3.65 & sandstone \\
\hline BB72 & 140 & 4.5 & Pliocene & -10.87 & -4.12 & sandstone \\
\hline BB73 & 144 & 4.0 & Pliocene & -10.57 & -3.79 & sandstone \\
\hline BB74 & 146.5 & 3.7 & Pliocene & -10.39 & -2.4 & sandstone \\
\hline BB75 & 148.5 & 3.5 & Pliocene & -10.44 & -3.38 & sandstone \\
\hline BB78 & 158 & 2.0 & Quaternary & -10.14 & -2.57 & unconsolidated sand \\
\hline BB79 & 162 & 0.8 & Quaternary & -10.47 & -2.79 & unconsolidated sand \\
\hline BB80 & 165 & 0.0 & $\begin{array}{l}\text { Quaternary } \\
\text { Taatsin Gol }\end{array}$ & -9.49 & -1.93 & unconsolidated sand \\
\hline \multicolumn{7}{|c|}{$\begin{array}{c}\text { Taatsin Gol } \\
\text { Section TGR-B }(45.4154 N 101.2631 E)\end{array}$} \\
\hline TGRB-5 & 5.46 & 36.0 & Eocene & -9.06 & -6.95 & pebble conglomerate \\
\hline TGRB-8b & 10.395 & 35.1 & Eocene & -9.48 & -7.57 & calcic paleosol \\
\hline TGRB-9 & 9.695 & 35.3 & Eocene & -9.63 & -7.73 & calcic paleosol \\
\hline TGRB-10 & 11.445 & 34.9 & Eocene & -9.39 & -7.24 & calcic paleosol \\
\hline TGRB-11 & 13.895 & 34.5 & Eocene & -8.67 & -7.22 & calcic paleosol \\
\hline TGRB-13 & 16.695 & 34.0 & Eocene & -8.85 & -7.26 & sandstone \\
\hline
\end{tabular}


TABLE A7

(continued)

\begin{tabular}{|c|c|c|c|c|c|c|}
\hline Sample ID & Height (m) & $\begin{array}{c}\text { Assigned } \\
\text { Age (Ma) }\end{array}$ & Epoch & $\delta^{18} \mathrm{O}$ & $\delta^{13} \mathrm{C}$ & Sample Type \\
\hline \multicolumn{7}{|c|}{ Section TGR-B (45.4154N 101.2631E) } \\
\hline TGRB-17 & 22.295 & 33.0 & Oligocene & -9.52 & -6.53 & carbonate-rich clay \\
\hline TGRB-18 & 23.695 & 32.7 & Oligocene & -9.40 & -6.85 & carbonate-rich clay \\
\hline TGRB-19 & 25.095 & 32.5 & Oligocene & -9.11 & -6.67 & carbonate-rich clay \\
\hline TGRB-21 & 27.895 & 32.0 & Oligocene & -8.88 & -6.82 & carbonate-rich clay \\
\hline TGRB-22 & 29.295 & 31.7 & Oligocene & -8.70 & -10.26 & carbonate-rich clay \\
\hline \multicolumn{7}{|c|}{ Section TGR-C (45.3864N 101.2268E) } \\
\hline TGRC-1 & 0 & 28.0 & Oligocene & -8.64 & -5.98 & carbonate-rich clay \\
\hline TGRC-2 & 2.5 & 27.4 & Oligocene & -9.12 & -5.78 & carbonate-rich clay \\
\hline TGRC-3 & 3 & 27.3 & Oligocene & -8.77 & -5.59 & carbonate-rich clay \\
\hline TGRC-4 & 4.25 & 27.0 & Oligocene & -8.98 & -5.61 & carbonate-rich clay \\
\hline TGRC-5 & 5.25 & 26.7 & Oligocene & -8.72 & -5.58 & carbonate-rich clay \\
\hline TGRC-6 & 5.5 & 26.7 & Oligocene & -8.82 & -5.71 & carbonate-rich clay \\
\hline TGRC-7 & 6 & 26.5 & Oligocene & -8.95 & -5.65 & carbonate-rich clay \\
\hline TGRC-8 & 6.5 & 26.4 & Oligocene & -8.98 & -5.72 & carbonate-rich clay \\
\hline TGRC-9 & 7 & 26.3 & Oligocene & -9.50 & -5.49 & carbonate-rich clay \\
\hline TGRC-10 & 7.5 & 26.2 & Oligocene & -9.10 & -5.72 & carbonate-rich clay \\
\hline TGRC-11 & 8 & 26.0 & Oligocene & -9.32 & -5.70 & carbonate-rich clay \\
\hline TGRC-12 & 8.25 & 26.0 & Oligocene & -8.96 & -5.92 & carbonate-rich clay \\
\hline TGRC-13 & 8.5 & 25.9 & Oligocene & -9.24 & -5.58 & carbonate-rich clay \\
\hline TGRC-14 & 8.75 & 25.9 & Oligocene & -9.13 & -5.25 & carbonate-rich clay \\
\hline TGRC-15a & 11 & 25.3 & Oligocene & -9.04 & -5.65 & carbonate-rich clay \\
\hline TGRC-15b & 11 & 25.3 & Oligocene & -9.54 & -6.28 & carbonate-rich clay \\
\hline TGRC-16 & 11.5 & 25.2 & Oligocene & -8.83 & -5.34 & carbonate-rich clay \\
\hline TGRC-17 & 12.25 & 25.0 & Oligocene & -8.43 & -4.90 & carbonate-rich clay \\
\hline \multicolumn{7}{|c|}{ Section TGL-A (45.4521N 101.2773E) } \\
\hline TGLA-18 & 8.5 & 13.0 & Miocene & -8.09 & -3.77 & carbonate-rich clay \\
\hline TGLA-19 & 8.5 & 13.0 & Miocene & -6.62 & -3.91 & caliche \\
\hline
\end{tabular}

${ }^{1}$ Taatsin Gol section names (TGR-B, TGR-C, and TGL-A) correspond to section names in Höck and others (1999).

\section{REFERENCES}

Barnes, C., and Allison, G., 1983, The distribution of deuterium and ${ }^{18} \mathrm{O}$ in dry soils 1 . Theory: Journal of Hydrology, v. 60, p. 141-156, 10.1016/0022-1694(83)90018-5

Bartoli, G., Hönisch, B., and Zeebe, R. E., 2011, Atmospheric $\mathrm{CO}_{2}$ decline during the Pliocene intensification of Northern Hemisphere glaciations: Paleoceanography, v. 26, n. 4, http://dx.doi.org/10.1029/ 2010PA002055

Beerling, D. J., and Royer, D. L., 2011, Convergent Cenozoic $\mathrm{CO}_{2}$ history: Nature Geoscience, v. 4, n. 7 , p. 418-420, http://dx.doi.org/10.1038/ngeo1186

Bershaw, J., Penny, S. M., and Garzione, C. N., 2012, Stable isotopes of modern water across the Himalaya and eastern Tibetan Plateau: Implications for estimates of paleoelevation and paleoclimate: Journal of Geophysical Research-Atmospheres, v. 117, n. D2, p. 1-18, http://dx.doi.org/10.1029/2011JD016132

Boos, W. R., and Kuang, Z., 2010, Dominant control of the South Asian monsoon by orographic insulation versus plateau heating: Nature, v. 463, p. 218-222, http://dx.doi.org/10.1038/nature08707

Borsuk-Bialynicka, M., 1969, Lower Pliocene rhinocerotids from Altan Teli, Western Mongolia: Palaeontologia Polonica, v. 21, p. 73-92.

Buslov, M. M., Kokh, D. A., and De Grave, J., 2008, Mesozoic-Cenozoic tectonics and geodynamics of Altai, Tien Shan, and Northern Kazakhstan, from apatite fission-track data: Russian Geology and Geophysics, v. 49, n. 9, p. 648-654, http://dx.doi.org/10.1016/j.rgg.2008.01.006

Cerling, T., and Quade, J., 1993, Stable Carbon and Oxygen Isotopes in Soil Carbonates, in Swart, P., Lohmann, K., McKenzie, J., and Savin, S. editors, Climate Change in Continental Isotopic Records: American Geophysical Union, Geophysical Monograph 78, p. 217-231, http://dx.doi.org/10.1029/ GM078p0217 
Cerling, T. E., 1984, The stable isotopic composition of modern soil carbonate and its relationship to climate: Earth and Planetary Science Letters, v. 71, n. 2, p. 229-240, http://dx.doi.org/10.1016/0012821X(84)90089-X

1991, Carbon dioxide in the atmosphere: Evidence from Cenozoic and Mesozoic paleosols: American Journal of Science, v. 291, n. 4, p. 377-400, http://dx.doi.org/10.2475/ajs.291.4.377

1999, Stable carbon isotopes in palaeosol carbonates, in Thiry, M., and Simon-Coincon, R. editors, Palaeoweathering, Palaeosurfaces and Related Continental Deposits: Oxford, United Kingdom, Blackwell, The International Association of Sedimentologists, p. 43-60, http://dx.doi.org/10.1002/ 9781444304190.ch2

Cerling, T. E., Harris, J. M., MacFadden, B. J., Leakey, M. G., Quade, J., Eisenmann, V., and Ehleringer, J. R., 1997, Global vegetation change through the Miocene/Pliocene boundary: Nature, v. 389, p. 153-158, http:/ /dx.doi.org/10.1038/38229

Charreau, J., Kent-Corson, M. L., Barrier, L., Augier, R., Ritts, B. D., Chen, Y., France-Lannord, C., and Guilmette, C., 2012, A high-resolution stable isotopic record from the Junggar Basin (NW China): Implications for the paleotopographic evolution of the Tianshan Mountains: Earth and Planetary Science Letters, v. 341-344, p. 158-169, http://dx.doi.org/10.1016/j.epsl.2012.05.033

Chen, F.-H., Chen, J.-H., Holmes, J., Boomer, I., Austin, P., Gates, J. B., Wang, N.-L., Brooks, S. J., and Zhang, J.-W., 2010, Moisture changes over the last millennium in arid central Asia: a review, synthesis and comparison with monsoon region: Quaternary Science Reviews, v. 29, n. 7-8, p. 1055-1068, http:// dx.doi.org/10.1016/j.quascirev.2010.01.005

Chen, S., Kuo, Y., Zhang, P., and Bai, Q., 1991, Synoptic Climatology of Cyclogenesis over East Asia, 1958-1987: Monthly Weather Review, v. 119, n. 6, p. 1407-1418, http://dx.doi.org/10.1175/15200493(1991) 119<1407:SCOCOE > 2.0.CO;2

Chung, Y., Hage, K., and Reinelt, E. R., 1976, On lee cyclogenesis and airflow in the Canadian Rocky Mountains and the East Asian Mountains: Monthly Weather Review, v. 104, p. 879-891, http:// dx.doi.org/10.1175/1520-0493(1976) 104〈0879:OLCAAI $\rangle 2.0 . C O ; 2$

Collatz, G. J., Berry, J. A., and Clark, J. S., 1998, Effects of climate and atmospheric CO2 partial pressure on the global distribution of $\mathrm{C}_{4}$ grasses: present, past, and future: Oecologia, v. 114, n. 4, p. 441-454, http:/ /dx.doi.org/10.1007/s004420050468

Cotton, J. M., and Sheldon, N. D., 2012, New constraints on using paleosols to reconstruct atmospheric $p \mathrm{CO}_{2}$ : Geological Society of America Bulletin, v. 124, n. 9-10, p. 1411-1423, http://dx.doi.org/10.1130/ B30607.1

Cunningham, W. D., 2001, Cenozoic normal faulting and regional doming in the southern Hangay region, Central Mongolia: implications for the origin of the Baikal rift province: Tectonophysics, v. 331, n. 4 , p. 389-411, http://dx.doi.org/10.1016/S0040-1951(00)00228-6

2005, Active intracontinental transpressional mountain building in the Mongolian Altai: Defining a new class of orogen: Earth and Planetary Science Letters, v. 240, n. 2, p. 436-444, http://dx.doi.org/ 10.1016/j.epsl.2005.09.013

2010, Tectonic setting and structural evolution of the Late Cenozoic Gobi Altai orogen: Geological Society, London, Special Publications, v. 338, p. 361-387, http://dx.doi.org/10.1144/SP338.17

Cunningham, W. D., Windley, B. F., Dorjnamjaa, D., and Saandar, M., 1996, Late Cenozoic transpression in southwestern Mongolia and the Gobi Altai-Tien Shan connection: Earth and Planetary Science Letters, v. 140, n. 1-4, p. 67-81, http://dx.doi.org/10.1016/0012-821X(96)00048-9

Czyzewski, T., 1969, Remains of the Lower Pliocene Bovidae from Altan Teli, Western Mongolia: Palaeontologia Polonica, v. 21, p. 95-104.

Davidson, G., 1995, The stable isotopic composition and measurement of carbon in soil $\mathrm{CO}_{2}$ : Geochimica et Cosmochimica Acta, v. 59, n. 12, p. 2485-2489, http://dx.doi.org/10.1016/0016-7037(95)00143-3

Daxner-Höck, G., and Badamgarav, D., 2007, Oligocene-Miocene vertebrates from the Valley of Lakes (Central Mongolia): morphology, phylogenetic, and stratigraphic implications: Geological and stratigraphic setting: Annalen des Naturhistorischen Museums in Wien, v. 108, Serie A, p. 1-24.

De Grave, J., Buslov, M. M., and Van den Haute, P., 2007, Distant effects of India-Eurasia convergence and Mesozoic intracontinental deformation in Central Asia: Constraints from apatite fission-track thermochronology: Journal of Asian Earth Sciences, v. 29, n. 2-3, p. 188-204, http://dx.doi.org/10.1016/ j.jseaes.2006.03.001

De Grave, J., Buslov, M. M., Van den Haute, P., Metcalf, J., Dehandschutter, B., and McWilliams, M. O., 2009, Multi-method chronometry of the Teletskoye graben and its basement, Siberian Altai Mountains: new insights on its thermo-tectonic evolution: Geological Society, London, Special Publications, v. 324, p. 237-259, http://dx.doi.org/10.1144/SP324.17

De Grave, J., De Pelsmaeker, E., Zhimulev, F. I., Glorie, S., Buslov, M. M., and Van den haute, P., 2014, Meso-Cenozoic building of the northern Central Asian Orogenic Belt: Thermotectonic history of the Tuva region: Tectonophysics, v. 621, p. 44-59, http://dx.doi.org/10.1016/j.tecto.2014.01.039

Delvaux, D., Cloetingh, S., Beekman, F., Sokoutis, D., Burov, E., Buslov, M. M., and Abdrakhmatov, K. E., 2013, Basin evolution in a folding lithosphere: Altai-Sayan and Tien Shan belts in Central Asia: Tectonophysics, v. 602, p. 194-222, http://dx.doi.org/10.1016/j.tecto.2013.01.010

Dettman, D. L., Fang, X., Garzione, C. N., and Li, J., 2003, Uplift-driven climate change at 12 Ma: a long $\delta^{18} \mathrm{O}$ record from the NE margin of the Tibetan plateau: Earth and Planetary Science Letters, v. 214, n. 1-2, p. 267-277, http://dx.doi.org/10.1016/S0012-821X(03)00383-2

Devyatkin, E. V, 1981, The Cenozoic of Inner Asia: Stratigraphy, geochronology and correlation: Moscow, Nauka, Transactions-The Joint Soviet-Mongolian Scientific-Research Geological Expedition, v. 27, p. 196.

Dickson, J. A. D., and Coleman, M. L., 1980, Changes in carbon and oxygen isotope composition during 
limestone diagenesis: Sedimentology, v. 27, n. 1, p. 107-118, http://dx.doi.org/10.1111/j.13653091.1980.tb01161.x

Ding, L., Xu, Q., Yue, Y., Wang, H., Cai, F., and Li, S., 2014, The Andean-type Gangdese Mountains: paleoelevation record from the Paleocene-Eocene Linzhou Basin: Earth and Planetary Science Letters, v. 392, p. 250-264, http://dx.doi.org/10.1016/j.epsl.2014.01.045

Draxler, R. R., and Hess, G. D., 1998, An overview of the HYSPLIT_4 modelling system for trajectories, dispersion, and deposition: Australian Meteorological Magazine, v. 47, p. 295-308.

Dupont-Nivet, G., Krijgsman, W., Langereis, C. G., Abels, H. A., Dai, S., and Fang, X., 2007, Tibetan plateau aridification linked to global cooling at the Eocene-Oligocene transition: Nature, v. 445, p. 635-638, http://dx.doi.org/10.1038/nature05516

Endo, N., Kadota, T., Matsumoto, J., Ailikun, B., and Yasunari, T., 2006, Climatology and trends in summer precipitation characteristics in Mongolia for the period 1960-98: Journal of the Meteorological Society of Japan, Series II, v. 84, n. 3, p. 543-551, http://dx.doi.org/10.2151/jmsj.84.543

Farquhar, G. D., O’Leary, M. H., and Berry, J. A., 1982, On the relationship between carbon isotope discrimination and the intercellular carbon dioxide concentration in leaves: Australian Journal of Plant Physiology, v. 9, n. 2, p. 121-137, http://dx.doi.org/10.1071/PP9820121

Farquhar, G. D., Ehleringer, J. R., and Hubick, K. T., 1989, Carbon isotope discrimination and photosynthesis: Annual Review of Plant Physiology and Plant Molecular Biology, v. 40, p. 503-537, http://dx.doi.org/ 10.1146/annurev.pp.40.060189.002443

Fluteau, F., Ramstein, G., and Besse, J., 1999, Simulating the evolution of the Asian and African monsoons during the past $30 \mathrm{Myr}$ using an atmospheric general circulation model: Journal of Geophysical Research-Atmospheres, v. 104, n. D10, p. 11995-12018, http://dx.doi.org/10.1029/1999JD900048

Foster, G. L., Lear, C. H., and Rae, J. W. B., 2012, The evolution of $\mathrm{pCO}_{2}$, ice volume and climate during the middle Miocene: Earth and Planetary Science Letters, v. 341-344, p. 243-254, http://dx.doi.org/ 10.1016/j.epsl.2012.06.007

Galewsky, J., 2009, Rain shadow development during the growth of mountain ranges: An atmospheric dynamics perspective: Journal of Geophysical Research-Earth Surface, v. 114, n. F1, p. 1-17, http:// dx.doi.org/10.1029/2008JF001085

Gerelchuluun, B., and Ahn, J.-B., 2013, Air temperature distribution over Mongolia using dynamical downscaling and statistical correction: International Journal of Climatology, v. 34, n. 7, p. 2464-2476, http://dx.doi.org/10.1002/joc.3853

Gottschalck, J., Meng, J., Rodell, M., and Houser, P., 2005, Analysis of multiple precipitation products and preliminary assessment of their impact on global land data assimilation system land surface states: Journal of Hydrometeorology, v. 6, p. 573-598, http://dx.doi.org/10.1175/JHM437.1

Goudie, A. S., and Pye, K., 1983, Chemical sediments and geomorphology: Precipitates and residua in the near-surface environment: London, Academic Press, 439 p.

Gradzinski, R., Kazmierczak, J., and Lefeld, J., 1969, Geographical and geological data from the PolishMongolian Palaeontological Expeditions: Palaeontologia Polonica, v. 19, p. 33-82.

Graham, S. A., Chamberlain, C. P., Yue, Y., Ritts, B. D., Hanson, A. D., Horton, T. W., Waldbauer, J. R., Poage, M. A., and Feng, X., 2005, Stable isotope records of Cenozoic climate and topography, Tibetan Palteau and Tarim Basin: American Journal of Science, v. 305, n. 2, p. 101-118, http://dx.doi.org/10.2475/ ajs.305.2.101

Guo, Z. T., Ruddiman, W. F., Hao, Q. Z., Wu, H. B., Qiao, Y. S., Zhu, R. X., Peng, S. Z., Wei, J. J., Yuan, B. Y., and Liu, T. S., 2002, Onset of Asian desertification by 22 Myr ago inferred from loess deposits in China: Nature, v. 416, p. 159-163, http://dx.doi.org/10.1038/416159a

Guo, Z. T., Sun, B., Zhang, Z. S., Peng, S. Z., Xiao, G. Q., Ge, J. Y., Hao, Q. Z., Qiao, Y. S., Liang, M. Y., Liu, J. F., Yin, Q. Z., and Wei, J. J., 2008, A major reorganization of Asian climate by the early Miocene: Climate of the Past, v. 4, n. 3, p. 153-174, http://dx.doi.org/10.5194/cp-4-153-2008

Höck, V., Daxner-Höck, G., Schmid, H. P., Badamgarav, D., Furtmuller, F. W., Montag, O., Barsbold, R., Khand, Y., and Sodov, J., 1999, Oligocene-Miocene sediments, fossils and basalts from the Valley of Lakes (Central Mongolia)-An Integrated study: Mitteilungen Osterreichischen Geolischen Gesellschaft, v. 90 , p. $83-125$.

Hough, B. G., Garzione, C. N., Wang, Z., Lease, R. O., Burbank, D. W., and Yuan, D., 2011, Stable isotope evidence for topographic growth and basin segmentation: Implications for the evolution of the NE Tibetan Plateau: Geological Society of America Bulletin, v. 123, n. 1-2, p. 168-185, http://dx.doi.org/ $10.1130 / \mathrm{B} 30090.1$

Howard, J. P., Cunningham, W. D., Davies, S. J., Dijkstra, A. H., and Badarch, G., 2003, The stratigraphic and structural evolution of the Dzereg Basin, western Mongolia: clastic sedimentation, transpressional faulting and basin destruction in an intraplate, intracontinental setting: Basin Research, v. 15, n. 1, p. 45-72, http://dx.doi.org/10.1046/j.1365-2117.2003.00198.x

Huxman, T. E., Smith, M. D., Fay, P. A., Knapp, A. K., Shaw, M. R., Loik, M. E., Smith, S. D., Tissue, D. T., Zak, J. C., Weltzin, J. F., Pockman, W. T., Sala, O. E., Haddad, B. M., Harte, J., Koch, G. W., Schwinning, S., Small, E. E., and Williams, D. G., 2004, Convergence across biomes to a common rain-use efficiency: Nature, v. 429, p. 1-4, http://dx.doi.org/10.1038/nature02561

Jolivet, M., Arzhannikov, S., Arzhannikova, A., Chauvet, A., Vassallo, R., and Braucher, R., 2013, Geomorphic Mesozoic and Cenozoic evolution in the Oka-Jombolok region (East Sayan ranges, Siberia): Journal of Asian Earth Sciences, v. 62, p. 117-133, http://dx.doi.org/10.1016/j.jseaes.2011.09.017

Kalnay, E., Kanamitsu, M., Kistler, R., Collins, W., Deaven, D., Gandin, L., Iredell, M., Saha, S., White, G., Woollen, J., Zhu, Y., Leetman, A., Reynolds, R., Chelliah, M., Ebisuzaki, W., Higgins, W., Janowiak, J., Mo, K. C., Ropelewski, C., Wang J., Jenne, R., and Joseph, D., 1996, The NCEP/NCAR 40-Year Reanalysis Project: Bulletin of the American Meteorological Society, v. 77, n. 3, p. 437-471, http://dx.doi.org/ 10.1175/1520-0477(1996)077〈0437:TNYRP $\rangle 2.0 . C O ; 2$ 
Kent-Corson, M. L., Ritts, B. D., Zhuang, G., Bovet, P. M., Graham, S. A., and Chamberlain, C. P., 2009, Stable isotopic constraints on the tectonic, topographic, and climatic evolution of the northern margin of the Tibetan Plateau: Earth and Planetary Science Letters, v. 282, n. 1-4, p. 158-166, http://dx.doi.org/ 10.1016/j.epsl.2009.03.011

Knapp, A. K., and Smith, M. D., 2001, Variation among biomes in temporal dynamics of aboveground primary production: Science, v. 291, n. 5503, p. 481-484, http://dx.doi.org/10.1126/science.291.5503.481

Kohn, M. J., 2010, Carbon isotope compositions of terrestrial C3 plants as indicators of (paleo)ecology and (paleo)climate.: Proceedings of the National Academy of Sciences of the United States of America, v. 107, n. 46, p. 19691-19695, http://dx.doi.org/10.1073/pnas.1004933107

Kraatz, B. P., and Geisler, J. H., 2010, Eocene-Oligocene transition in Central Asia and its effects on mammalian evolution: Geology, v. 38, n. 2, p. 111-114, http://dx.doi.org/10.1130/G30619.1

Lechler, A. R., and Galewsky, J., 2013, Refining paleoaltimetry reconstructions of the Sierra Nevada, California, using air parcel trajectories: Geology, v. 41, n. 2, p. 259-262, http://dx.doi.org/10.1130/ G33553.1

Lydolph, P. E., 1977, Climates of the Soviet Union: New York, Elsevier, 456 p.

Miao, Y., Herrmann, M., Wu, F., Yan, X., and Yang, S., 2012, What controlled Mid-Late Miocene long-term aridification in Central Asia?-Global cooling or Tibetan Plateau uplift: A review: Earth-Science Reviews, v. 112, n. 3-4, p. 155-172, http://dx.doi.org/10.1016/j.earscirev.2012.02.003

Mix, H. T., Winnick, M. J., Mulch, A., and Chamberlain, C. P., 2013, Grassland expansion as an instrument of hydrologic change in Neogene western North America: Earth and Planetary Science Letters, v. 377-378, p. 73-83, http://dx.doi.org/10.1016/j.epsl.2013.07.032

Molnar, P., Boos, W. R., and Battisti, D. S., 2010, Orographic controls on climate and paleoclimate of Asia: thermal and mechanical roles for the Tibetan Plateau: Annual Review of Earth and Planetary Sciences, v. 38, n. 1, p. 77-102, http://dx.doi.org/10.1146/annurev-earth-040809-152456

Myers, T. S., Tabor, N. J., Jacobs, L. L., and Mateus, O., 2012, Estimating soil $p \mathrm{CO}_{2}$ using paleosol carbonates: implications for the relationship between primary productivity and faunal richness in ancient terrestrial ecosystems: Paleobiology, v. 38, n. 4, p. 585-604, http://dx.doi.org/10.1666/11005.1

Nandintsetseg, B., and Shinoda, M., 2011, Seasonal change of soil moisture in Mongolia: its climatology and modelling: International Journal of Climatology, v. 31, n. 8, p. 1143-1152, http://dx.doi.org/10.1002/ joc. 2134

Numaguti, A., 1999, Origin and recycling processes of precipitating water over the Eurasian continent: Experiments using an atmospheric general circulation model: Journal of Geophysical ResearchAtmospheres, v. 104, n. D2, p. 1957-1972, http://dx.doi.org/10.1029/1998JD200026

Panagiotopoulos, F., Shahgedanova, M., Hannachi, A., and Stephenson, D. B., 2005, Observed trends and teleconnections of the Siberian High: a recently declining center of action: Journal of Climate, v. 18, n. 9, p. 1411-1422, http://dx.doi.org/10.1175/JCLI3352.1

Park, H.-S., Chiang, J. C. H., and Son, S.-W., 2010, The role of the central Asian mountains on the midwinter suppression of North Pacific storminess: Journal of the Atmospheric Sciences, v. 67, n. 11, p. $3706-$ 3720, http://dx.doi.org/10.1175/2010JAS3349.1

Park, R., and Epstein, S., 1960, Carbon isotope fractionation during photosynthesis: Geochimica et Cosmochimica Acta, v. 21, n. 1-2, p. 110-126, http://dx.doi.org/10.1016/S0016-7037(60)80006-3

Passey, B. H., Ayliffe, L. K., Kaakinen, A., Zhang, Z., Eronen, J. T., Zhu, Y., Zhou, L., Cerling, T. E., and Fortelius, M., 2009, Strengthened East Asian summer monsoons during a period of high-latitude warmth? Isotopic evidence from Mio-Pliocene fossil mammals and soil carbonates from northern China: Earth and Planetary Science Letters, v. 277, n. 3-4, p. 443-452, http://dx.doi.org/10.1016/ j.epsl.2008.11.008

Penny, S., Roe, G. H., and Battisti, D. S., 2010, The source of the midwinter suppression in storminess over the North Pacific: Journal of Climate, v. 23, n. 3, p. 634-648, http://dx.doi.org/10.1175/2009JCLI2904.1

Popov, S. V., Rögl, F., Rozanov, A. Y., Steininger, F. F., Shcherba, I. G., and Kovac, M., 2004, LithologicalPaleogeographic maps of Paratethys: Frankfurt am Main, Courier Forschungsinstitut Senckenberg, 250.

Pyankov, V. I., Gunin, P. D., Tsoog, S., and Black, C. C., 2000, C 4 plants in the vegetation of Mongolia: their natural occurrence and geographical distribution in relation to climate: Oecologia, v. 123, n. 1, p. 15-31, http://dx.doi.org/10.1007/s004420050985

Quade, J., Cerling, T. E., and Bowman, J., 1989, Systematic variations in the carbon and oxygen isotopic composition of pedogenic carbonate along elevation transects in the southern Great Basin, United States: Geological Society of America Bulletin, v. 101, n. 4, p. 464-475, http://dx.doi.org/10.1130/00167606(1989) 101<0464:SVITCA $>2.3 . C O ; 2$

Quade, J., Breecker, D. O., Daeron, M., and Eiler, J., 2011, The paleoaltimetry of Tibet: An isotopic perspective: American Journal of Science, v. 311, n. 2, p. 77-115, http://dx.doi.org/10.2475/ 02.2011 .01

Raich, J. W., and Schlesinger, W. H., 1992, The global carbon dioxide flux in soil respiration and its relationship to vegetation and climate: Tellus B, v. 44B, n. 2,p. 81-99, http://dx.doi.org/10.1034/j.16000889.1992.t01-1-00001.x

Retallack, G. J., 1994, The Environmental Factor Approach to the Interpretation of Paleosols, in Amundson, R., Harden, J. W., and Singer, M., editors, Factors of Soil Formation: A Fiftieth Anniversary Retrospective: Soil Science Society of America Special Publication 33, p. 31-64, http://dx.doi.org/10.2136/ sssaspecpub33.c3

- 2005, Pedogenic carbonate proxies for amount and seasonality of precipitation in paleosols: Geology, v. 33, n. 4, p. 333-336, http://dx.doi.org/10.1130/G21263.1

Roe, G., 2009, On the interpretation of Chinese loess as a paleoclimate indicator: Quaternary Research, v. 71, n. 2, p. 150-161, http://dx.doi.org/10.1016/j.yqres.2008.09.004 
Rowley, D. B., and Currie, B. S., 2006, Palaeo-altimetry of the late Eocene to Miocene Lunpola basin, central Tibet: Nature, v. 439, p. 677-681, http://dx.doi.org/10.1038/nature04506

Sato, T., 2009, Influences of subtropical jet and Tibetan Plateau on precipitation pattern in Asia: Insights from regional climate modeling: Quaternary International, v. 194, n. 1-2, p. 148-158, http://dx.doi.org/ 10.1016/j.quaint.2008.07.008

Sato, T., and Kimura, F., 2005, Impact of diabatic heating over the Tibetan Plateau on subsidence over northeast Asian arid region: Geophysical Research Letters, v. 32, n. 5, p. L05809, http://dx.doi.org/ $10.1029 / 2004$ GL022089

Sato, T., Tsujimura, M., Yamanaka, T., Iwasaki, H., Sugimoto, A., Sugita, M., Kimura, F., Davaa, G., and Oyunbaatar, D., 2007, Water sources in semiarid northeast Asia as revealed by field observations and isotope transport model: Journal of Geophysical Research-Atmospheres, v. 112, n. D17, p. D17112, http:/ / dx.doi.org/10.1029/2006JD008321

Schneider, U., Becker, A., Finger, P., Mever-Christoffer, A., Rudolf, B., and Ziese, M., 2011, GPCC Full Data Reanalysis Version 6.0 at $0.5^{\circ}$ : Monthly Land-Surface Precipitation from Rain-Gauges built on the GTS-based and Historic Data, http://dx.doi.org10.5676/DWD_GPCC/FD_M_V6_050

Shao, Y., and Dong, C. H., 2006, A review on East Asian dust storm climate, modelling and monitoring: Global and Planetary Change, v. 52, n. 1-4, p. 1-22, http://dx.doi.org/10.1016/j.gloplacha.2006.02.011

Sinclair, K. E., Marshall, S. J., and Moran, T. A., 2011, A Lagrangian approach to modelling stable isotopes in precipitation over mountainous terrain: Hydrological Processes, v. 25, n. 16, p. 2481-2491, http:// dx.doi.org/10.1002/hyp.7973

Sjostrom, D. J., and Welker, J. M., 2009, The influence of air mass source on the seasonal isotopic composition of precipitation, eastern USA: Journal of Geochemical Exploration, v. 102, n. 3, p. 103112, http://dx.doi.org/10.1016/j.gexplo.2009.03.001

Still, C. J., Berry, J. A., Collatz, G. J., and DeFries, R. S., 2003, Global distribution of $\mathrm{C}_{3}$ and $\mathrm{C}_{4}$ vegetation: Carbon cycle implications: Global Biogeochemical Cycles, v. 17, n. 1, http://dx.doi.org/10.1029/ $2001 \mathrm{~GB} 001807$

Sun, D., Shaw, J., Zhisheng, A., Minyang, C., and Leping, Y., 1998, Magnetostratigraphy and paleoclimatic interpretation of a continuous 7.2 Ma Late Cenozoic eolian sediments from the Chinese Loess Plateau: Geophysical Research Letters, v. 25, n. 1, p. 85-88, http://dx.doi.org/10.1029/97GL03353

Sun, J., Ye, J., Wu, W., Ni, X., Bi, S., Zhang, Z., Liu, W., and Meng, J., 2010, Late Oligocene-Miocene mid-latitude aridification and wind patterns in the Asian interior: Geology, v. 38, n. 6, p. 515-518, http://dx.doi.org/10.1130/G30776.1

Sun, Y., An, Z., Clemens, S. C., Bloemendal, J., and Vandenberghe, J., 2010, Seven million years of wind and precipitation variability on the Chinese Loess Plateau: Earth and Planetary Science Letters, v. 297, n. 3-4, p. 525-535, http://dx.doi.org/10.1016/j.epsl.2010.07.004

Takeuchi, A., Hren, M. T., Smith, S. V., Chamberlain, C. P., and Larson, P. B., 2010, Pedogenic carbonate carbon isotopic constraints on paleoprecipitation: Evolution of desert in the Pacific Northwest, USA, in response to topographic development of the Cascade Range: Chemical Geology, v. 277, n. 3-4, p. 323-335, http://dx.doi.org/10.1016/j.chemgeo.2010.08.015

Tapponnier, P., and Molnar, P., 1979, Active faulting and Cenozoic tectoonics of the Tien Shan, Mongolia, and Baykal regions: Journal of Geophysical Research-Solid Earth, v. 84, n. B7, p. 3425-3459, http:// dx.doi.org/10.1029/JB084iB07p03425

Tipple, B. J., Meyers, S. R., and Pagani, M., 2010, Carbon isotope ratio of Cenozoic $\mathrm{CO}_{2}$ : A comparative evaluation of available geochemical proxies: Paleoceanography, v. 25, n. 3, http://dx.doi.org/10.1029/ 2009PA001851

Toderich, K., Black, C. C., Juylova, E., Kozan, O., Mukimov, T., and Matsuo, N., 2007, C3/C4 plants in the vegetation of Central Asia, geographical distribution and environmental adaptation in relation to climate, in Lal, R., Suleimenovv, M., Stewart, B. A., Hansen, D. O., and Doraiswamy, P., editors, Climate Change and Terrestrial Carbon Sequestration in Central Asia: London, Taylor \& Francis, p. 33-63, http://dx.doi.org/10.1201/9780203932698.ch3

Traynor, J. J., and Sladen, C., 1995, Tectonic and stratigraphic evolution of the Mongolian People's Republic and its influence on hydrocarbon geology and potential: Marine and Petroleum Geology, v. 12, n. 1, p. 35-52, http:/ /dx.doi.org/10.1016/0264-8172(95)90386-X

Vassallo, R., Jolivet, M., Ritz, J.-F., Braucher, R., Larroque, C., Sue, C., Todbileg, M., and Javkhlanbold, D., 2007, Uplift age and rates of the Gurvan Bogd system (Gobi-Altay) by apatite fission track analysis: Earth and Planetary Science Letters, v. 259, n. 3-4, p. 333-346, http:// dx.doi.org/10.1016/j.epsl.2007.04.047

Wang, C., Zhao, X., Liu, Z., Lippert, P. C., Graham, S. A., Coe, R. S., Yi, H., Zhu, L., Liu, S., and Li, Y., 2008, Constraints on the early uplift history of the Tibetan Plateau: Proceedings of the National Academy of Sciences of the United States of America, v. 105, n. 13, p. 4987-4992, http://dx.doi.org/10.1073/ pnas.0703595105

Wang, Y., and Deng, T., 2005, A 25 m.y. isotopic record of paleodiet and environmental change from fossil mammals and paleosols from the NE margin of the Tibetan Plateau: Earth and Planetary Science Letters, v. 236, n. 1-2, p. 322-338, http://dx.doi.org/10.1016/j.epsl.2005.05.006

West, A. J., Fox, M., Walker, R. T., Carter, A., Harris, T., Watts, A. B., and Gantulga, B., 2013, Links between climate, erosion, uplift, and topography during intracontinental mountain building of the Hangay Dome, Mongolia: Geochemistry, Geophysics, Geosystems, v. 14, n. 12, p. 5171-5193, http://dx.doi.org/ 10.1002/2013GC004859

Wittmer, M. H. O. M., Auerswald, K., Tungalag, R., Bai, Y. F., Schäufele, R., Bai, C. H., and Schnyder, H., 2008, Carbon isotope discrimination of C3 vegetation in Central Asian Grassland as related to long-term and short-term precipitation patterns: Biogeosciences, v. 5, p. 913-924, http://dx.doi.org/10.5194/bg5-913-2008

Yarmolyuk, V. V., Kudryashova, E. A., Kozlovsky, A. M., and Lebedev, V. A., 2008, Late Cenozoic volcanism of 
Khangai (Central Mongolia): Evidence for recent orogeny in Central Asia: Doklady Earth Sciences, v. 422, n. 1, p. 1032-1036, http://dx.doi.org/10.1134/S1028334X08070064

Yin, A., 2010, Cenozoic tectonic evolution of Asia: A preliminary synthesis: Tectonophysics, v. 488, n. 1-4, p. 293-325, http://dx.doi.org/10.1016/j.tecto.2009.06.002

Yuan, D.-Y., Ge, W.-P., Chen, Z.-W., Li, C.-Y., Wang, Z.-C., Zhang, H.-P., Zhang, P.-Z., Zheng, D.-W., Zheng, W.-J., Craddock, W. H., Dayem, K. E., Duvall, A. R., Hough, B. G., Lease, R. O., Champagnac, J.-D., Burbank, D. W., Clark, M. K, Farley, K. A., Garzione, C. N., Kirby, E., Molnar, P., and Roe, G. H., 2013, The growth of northeastern Tibet and its relevance to large-scale continental geodynamics: A review of recent studies: Tectonics, v. 32, n. 5, p. 1358-1370, http://dx.doi.org/10.1002/tect.20081

Zachos, J., Pagani, M., Sloan, L., Thomas, E., and Billups, K., 2001, Trends, rhythms, and aberrations in global climate 65 Ma to present: Science, v. 292, n. 5517, p. 686-693, http://dx.doi.org/10.1126/ science.1059412

Zhang, C., Wang, Y., Deng, T., Wang, X., Biasatti, D., Xu, Y., and Li, Q., 2009, C4 expansion in the central Inner Mongolia during the latest Miocene and early Pliocene: Earth and Planetary Science Letters, v. 287, n. 3-4, p. 311-319, http://dx.doi.org/10.1016/j.epsl.2009.08.025

Zhang, Y. G., Pagani, M., Liu, Z., Bohaty, S. M., and Deconto, R., 2013, A 40-million-year history of atmospheric $\mathrm{CO}_{2}$ : Philosophical Transactions of the Royal Society A, v. 371, n. 2001, http://dx.doi.org/ 10.1098/rsta.2013.0096

Zhuang, G., Hourigan, J. K., Koch, P. L., Ritts, B. D., and Kent-Corson, M. L., 2011, Isotopic constraints on intensified aridity in Central Asia around 12 Ma: Earth and Planetary Science Letters, v. 312, n. 1-2, p. 152-163, http://dx.doi.org/10.1016/j.epsl.2011.10.005 